\title{
Journey of TRAIL from bench to bedside and its potential role in immuno-oncology
}

\author{
George E. Naoum, ${ }^{1}$ Donald J. Buchsbaum, ${ }^{2}$ Fady Tawadros, ${ }^{3}$ Ammad Farooqi, ${ }^{4}$ Waleed O. Arafat ${ }^{1,2,5}$ \\ ${ }^{1}$ Alexandria Comprehensive Cancer Center, Alexandria, Egypt; ${ }^{2}$ Univeristy of Alabama, Birmingham, AL, USA; \\ ${ }^{3}$ East Tennessee State University, TN, USA; ${ }^{4}$ Rashid Latif Medical College, Pakistan; ${ }^{5}$ University of Alexandria, \\ Faculty of Medicine, Egypt
}

\begin{abstract}
Induction of apoptosis in cancer cells has increasingly been the focus of many therapeutic approaches in oncology field. Since its identification as a TNF family member, TRAIL (TNF-related apoptosis-inducing ligand) paved a new path in apoptosis inducing cancer therapies. Its selective ability to activate extrinsic and intrinsic cell death pathways in cancer cells only, independently from p53 mutations responsible for conventional therapeutics resistance, spotted TRAIL as a potent cancer apoptotic agent. Many recombinant preparations of TRAIL and death receptor targeting monoclonal antibodies have been developed and being tested pre-clinically and clinically both as a single agent and in combinations. Of note, the monoclonal antibodies were not the only type of antibodies developed to target TRAIL receptors. Recent technology has brought forth several single chain variable domains ( $\mathrm{scFv}$ ) designs fused recombinantly to TRAIL as well. Also, it is becoming progressively more understandable that field of nanotechnology has revolutionized cancer diagnosis and therapy. The recent breakthroughs in materials science and protein engineering have helped considerably in strategically loading drugs into nanoparticles or conjugating drugs to their surface. In
\end{abstract}

Correspondence: Waleed O. Arafat, Clinical Oncology Department, Alexandria University, Faculty of Medicine, 1 Midan el Khartoum, Alexandria 00203, Egypt.

E-mail:w.o.arafaat@gmail.com

Key words: TRAIL; apoptosis; nanotechnology; single chain antibody.

Contributions: George E. Naoum main and primary author and all other authors contributed equally.

Conflict of interest: the authors declare no potential conflict of interest.

Ethical approval: this article does not contain any studies with human participants or animals performed by any of the authors.

Received for publication: 24 December 2016.

Revision received: 17 February 2017.

Accepted for publication: 27 February 2017.

This work is licensed under a Creative Commons Attribution NonCommercial 4.0 License (CC BY-NC 4.0).

CC Copyright G.E. Naoum et al., 2017

Licensee PAGEPress, Italy

Oncology Reviews 2017; 11:332

doi:10.4081/oncol.2017.332 this review we aim to comprehensively highlight the molecular knowledge of TRAIL in the context of its pathway, receptors and resistance factors. We also aim to review the clinical trials that have been done using TRAIL based therapies and to review various scFv designs, the arsenal of nano-carriers and molecules available to selectively target tumor cells with TRAIL.

\section{Introduction}

Despite the current advances in medicine, the cancer field remains one of the not fully conquered fields in medicine. Thousands of researches have been dedicated to better understand the complex biology of that disease and to achieve a magic bullet treatment. Resection of the tumor mass, along with irradiation and chemotherapy aiming to killing mutant cells were and remain considerable treatment options. Unfortunately, these options have been encountered by many obstacles including partial response, poor quality of life, and even resistance leading sometimes to metastasis. These facts, along with complex molecular pathways implicated in cancer development, urged scientists to search for alternative precise treatment options. In this regard, targeting only genetic mutations, responsible for many cancers, may not be an ultimate cure. Therefore selectively inducing apoptosis in cancer cells appeal as a promising approach. ${ }^{1}$ Apoptosis is a complex process controlled by multiple signaling pathways and molecules. In mid 1990's, a new 281-amino acid type II trans-membrane protein coined TRAIL (tumor necrosis factor-related apoptosis-inducing ligand or Apo 2 ligand, was identified as a member of TNF family based on extracellular domain sequence homology with TNF (23\% identical) and CD95L (28\% identical). ${ }^{2}$ The major biological role of TRAIL is apoptosis induction after interacting with its receptors to activate the extrinsic and intrinsic pathways of cell death. ${ }^{3-5}$ Of note, a suitable apoptosis inducer agent should possess a selective nature in order to spare normal tissues. The advances in molecular biology field has led to better understanding and characterizing TRAIL nature and properties, including a selective nature to cancer cells. Since then, the emergence of TRAIL as a promising apoptotic molecule, encouraged many translational laboratories to create the optimum preparation of that molecule to be used clinically.

Indeed many TRAIL based therapies have been created and tested in clinical field. However, the search for an optimum TRAIL preparation using many advanced technologies is still undergoing.

Also better understanding of the tumor microenvironment sparked the so-called immune modulating therapies aiming to enhance the innate immune system response against malignant cells. The role of TRAIL in such approach should not be belittled, 
as many recent studies, which will be discussed later in this review, found links between immunomodulation and TRAIL.

In this review we aim to comprehensively discuss the journey of TRAIL from bench to bedside; Focusing on the complex TRAIL molecular biology, its role in cancer and the clinical trials that have tested its clinical benefits. We also aim to discuss the role of different advanced technologies as single chain antibodies and nanotechnologies in creating an optimum TRAIL preparation

\section{TRAIL molecular biology}

The TNF family members in general are known for their major role in various biological and immune processes. TNF $\alpha$, one of the first characterized members of this family, is known for its tight transient expression by immune cells mainly in certain circumstances. ${ }^{6}$ Two main receptors for TNF $\alpha$ have been classified; ${ }^{7}$ TNFR-1 containing an intracellular death domain capable of activating the extrinsic apoptosis pathway through caspases. TNFR-2 is the other TNF receptor, lacking this death domain, able to induce both cell proliferation through NFkB activation and cell apoptosis in a very complex balanced process. ${ }^{7,8}$ Unlike TNF, TRAIL mRNA is widely expressed in variable tissues normally not under specific immunological circumstances. ${ }^{2}$ Also, none of TRAIL receptors were found to induce cell proliferation like the controversial TNFR-2 for TNF. In the following part we are going to discuss TRAIL receptors and their downstream signaling.

\section{TRAIL receptors}

TRAIL transduced the signals intracellularly through different receptors. These are: DR4/TRAIL-R1, DR5/TRAIL-R2, DcR1/TRAIL-R3, and DcR2/TRAIL-R4. ${ }^{9-12}$ The death receptors DR4 (TRAIL-R1) and DR5 (TRAIL-R2), contained a death domain motif and played an important role in transduction of the signals to induce apoptosis in cancer cells. ${ }^{13,14}$ The other receptors are TRAIL-R3/DcR1 (glycosyl-phosphatidyl-inositol-anchored receptor lacking an intracellular domain), and a truncated TRAILR4/DcR2 (containing non-functional DD in its intracellular domain). Out of the 76 amino acids coding for TRAIL-R1 and TRAIL-R2 death domains, the non-functional domain of TRAILR4/DcR 2 contain only 24 plus additional 22 residues at the end of coding sequence. The only part missing in DcR2 intracellular domain in comparison to DR4 and DR5 is the part responsible for apoptosis induction. The extracellular homology of DcR1 and DcR2 to the DR4 and DR5 allow them to act as decoy receptors binding to TRAIL but not able to induce apoptosis due to their disrupted intracellular domain as described. ${ }^{13,15}$ Despite the fact, that TRAIL receptors mRNA expression is widely extended in both normal and malignant tissues, ${ }^{16,17}$ normal cells were found to be less responsive to TRAIL due to the abundancy of DcR1 and DcR2 in comparison to cancer cells. ${ }^{18}$

Many types of cancer cells showed to be more sensitive and responsive to TRAIL apoptotic effects. ${ }^{17}$ It was found that DR4 and/or DR5 are present and expressed in pancreatic cancer, colon cancer, breast cancer, glioblastoma multiforme, primary and metastatic head and neck squamous cell carcinoma, cervical and ovarian cancer, non-small cell lung carcinoma and finally bladder cancer. ${ }^{19-27}$

The binding of TRAIL to its death receptor, leads to the activation of two main signaling cascades for cell death; extrinsic and intrinsic pathways. ${ }^{28}$

\section{Extrinsic pathway of apoptosis}

Cell extrinsic pathway initiated upon binding of TRAIL to either DR4 or DR5 that resulted in the formation of homotrimers. ${ }^{29,30}$ This trimeric ligand needs a $\mathrm{Zn}$ atom bound by cysteines for its stability and optimum biological activity. ${ }^{31}$ This trimerization of receptors resulted in formation of a macromolecular complex, known as DISC (Death-inducing signaling complex). In this complex, an adaptor molecule known as FADD (Fas associated death domain protein), is recruited and interacted with caspase- 8 and -10 to activate these molecules.

For stabilization of activated caspase-8, the E3 ligase Cullin3 induces poly-ubiquitination of caspase- 8 and subsequent recruitment of the ubiquitin-binding protein p62, which stabilizes activated caspase- 8 , thereby ensuring DISC activation and functioning. ${ }^{32}$ The caspase- 8 and -10 , when activated, triggered pro-caspase- 3 conversion into its functionally active form.

Interestingly, it was found that both of the apoptotic pathways the extrinsic and the intrinsic communicate with each other ${ }^{33,34}$ as shown in Figure 1A.

\section{Intrinsinc pathway of apoptosis}

Upon death stimulus, active caspase- 8 cleaves Bid (a member the proapoptotic Bcl-2 family). This cleavage leads to the formation of a proteolytically processed form of Bid known as truncated Bid (tBid) which interacts with Bak and Bax in mitochondria to destabilize its outer membrane and induce cytosolic accumulation of cytochrome $c$. In the cytoplasm, cytochrome $c$ interacted with pro-caspase- 9 and APAF-1 as shown in Figure 1A, that consequently formed a signalosome known as an apoptosome. Apoptosome mediated activation of Caspase-9 further activated 'executioner' caspases.

This connection mechanistically played a critical role in amplification of the response to activation of death receptors and diverse types of cells have been studied to be dependent on this amplification pathway. ${ }^{35}$ Therefore based on the apoptotic pathway that the cell employs after DISC activation, cells have been classified in two categories. ${ }^{36,37}$ The two categories are type-I and type-II cells.

Type-I cells, depends mainly on extrinsic apoptotic pathway as activation of DISC in these cells is stable enough to trigger robust activation of caspase-8, which further activates its downstream effector caspase-3, resulting in cell death. In type-II cells, the DISC signaling leading to caspase-3 activation is inadequate to trigger apoptotic cell death, therefore these cells rely more on mitochondrial intrinsic pathway for cell death. However, more recently it was reported that the cell's ability to form efficient DISC is not the only distinguishing factor between type- 1 and type- 2 cells. Another crucial element for making this distinction, is the anti-apoptotic factor XIAPs (X-linked inhibitor of apoptosis proteins). ${ }^{38}$

XIAP reverses induction of apoptosis via direct inhibition of caspase- $3 .{ }^{39}$ In type-II cells higher ratio of XIAP/caspase-3 resulted in an incomplete activation of caspase- 3 by caspase- 8 . Data clearly suggested that ratio of XIAP to caspase- 3 and the DISC's capacity to cleave caspase- 3 were decisive for differentiation between type-II and type-I cells.

In addition to above-mentioned mechanism for induction of apoptosis, it was demonstrated that TNF, CD95L and TRAIL are able to induce programmed cell death by necrosis or "Necroptosis".

\section{TRAIL and necroptosis}

Necroptosis is a pathological term that is used to describe programmed necrotic cell death dependent on receptor-interacting protein kinase-3 (RIPK3). ${ }^{40}$

Necroptosis occurs when cellular death receptors activate the apoptotic machinery reflecting an intricate network of signals that 
operate and that can 'switch' between different patterns of responses. ${ }^{41,42}$ Activated caspase 8 , by TRAIL receptors signaling, inactivates RIP1 and RIP3 by proteolytic cleavage and initiates the proapoptotic caspase activation cascade. However in absence or inhibition of caspase 8 by pharmacological agents, RIP1 and RIP3 become phosphorylated and thus able to initiate necroptosis. ${ }^{43}$ Activation of RIPK1 and RIPK3 subsequently results in phosphorylation of mixed lineage kinase domain-like protein (MLKL), then they contribute to its trimerization. Cai et al. suggested that trimerized MLKL locates at the plasma membrane and causes TRPM7-mediated calcium influx initiating process of necroptosis. ${ }^{44}$

Figure 2 shows different proteins, which trigger necroptosis.

\section{Mechanisms attenuating TRAIL apoptotic effects}

Several mechanisms and molecules have been suggested to alter the cytotoxic effects induced by TRAIL. These exhibit their action by interfering with the induction of either the extrinsic or intrinsic apoptotic pathways activated through TRAIL.

\section{Attenuating TRAIL induced extrinsic pathway}

It was found, that neuroblastoma cell lines (NB) are resistant to TRAIL induced apoptosis. This finding can be attributed to the fact that large subset of these cell lines lack caspase- 8 and -10 expression. ${ }^{45}$ However, the same study by Eggert et al. showed that; there are also other factors than the lack of caspase- 8 and/or 10 expression in NB cells that might be responsible for TRAILinduced apoptosis resistance.

Among these factors is c-FLIP (cellular FLICE inhibitory pro- tein). The inhibitory effects of this protein, comes from the fact that it shares homologous sequence with caspase 8 . This similarity might leads to competitive binding between caspase- 8 and FADD on the binding sites in DISC, as shown in Figure 1B. Also, in the presence of c-FLIP, DISC forms a secondary complex with TRADD (TNFR1-associated death domain), receptor-interacting protein (RIP), NFkB kinase, and TNF receptor-associated factor 2 (TRAF2). TRAF2 mediates the attachment of K48-linked ubiquitin chains to caspase-8, allowing its proteosomal degradation and, hence, limitation of DISC activity in this secondary complex. ${ }^{46}$ Moreover, this multi-protein complex activated proliferative signals initiated through the MAPK (mitogen-activated protein kinase) pathways, phosphoinositide 3-kinase (PI3K)/Akt and nuclear factor $\kappa \mathrm{B}$.

Interleukine 8 (IL-8) was found to inhibit TRAIL-induced apoptosis. ${ }^{47,48}$ It was concluded that IL-8 induce the expression of two isoforms of c-FLIP, the c-FLIP(L) and c-FLIP(S), and its inhibition lead to a significant decrease in the mRNA transcript levels of c-FLIP. ${ }^{48}$

\section{Attenuating TRAIL induced intrinsic pathway}

Another factor identified for TRAIL resistance was the inhibitor of apoptosis (IAP) family, which included survivin, Xlinked IAP, cellular IAP-1 and -2. These molecules - as described earlier - inhibit the activity of caspases 3, 7 and/or9 and hence contributing to TRAIL resistance.

Nevertheless, during apoptosis, Bax leads to the release of Smac (second mitochondria-derived activator of caspases) from mitochondria, these two can antagonize (IAPs) effect.(49) This role explained why mutation or inactivation of Bax in mismatchrepair (MMR)- deficient tumors resulted in development of TRAIL resistance. TRAIL responsiveness of cancer cells reconsti-

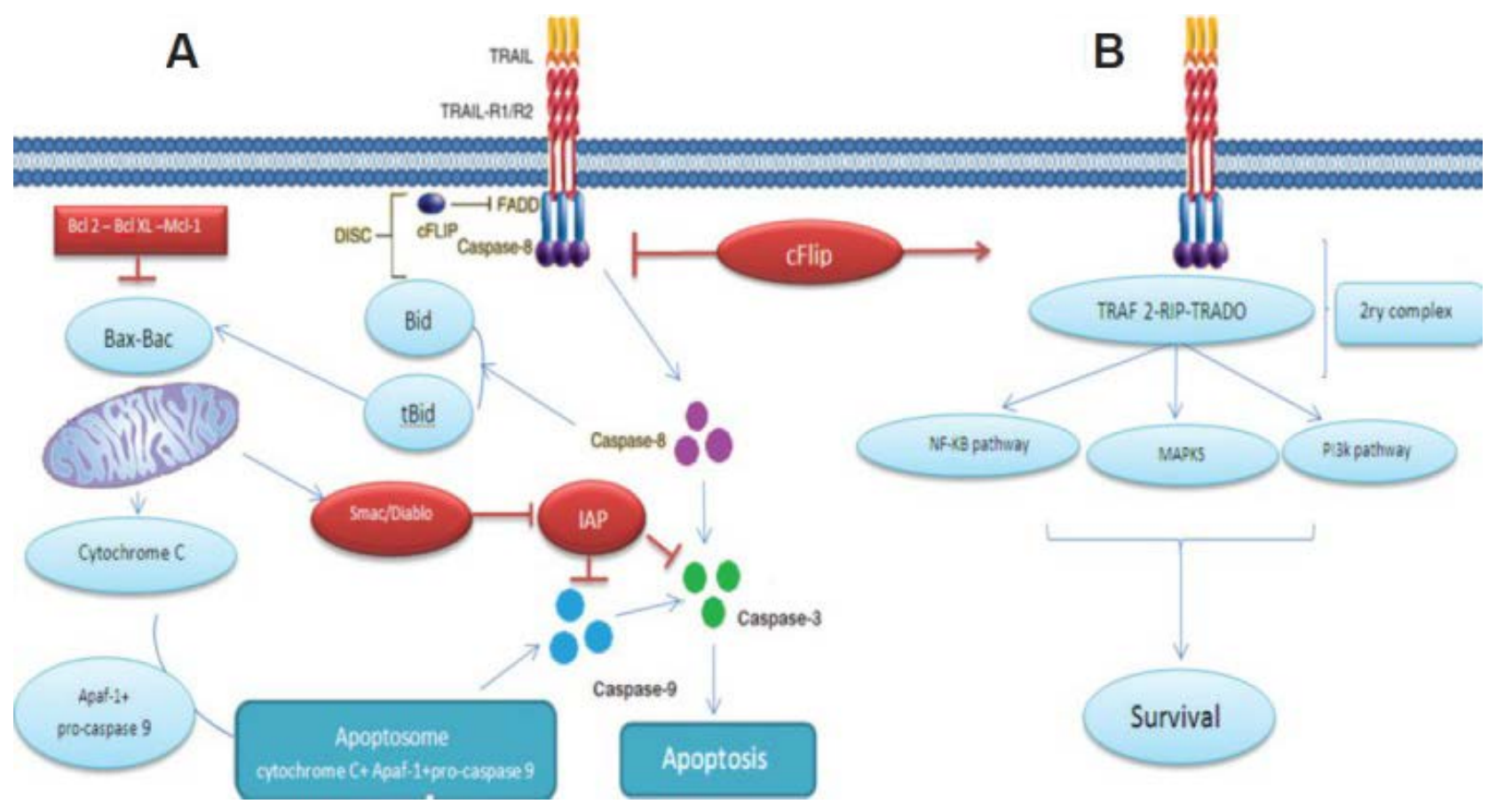

Figure 1. Showing the TRAIL signalling pathway: A) the apoptotic pathway induced by TRAIL; and B) the resistance to TRAIL induced apoptosis. Binding of TRAIL and trimerisation of TRAIL death receptors leads to recruitment of FADD, an adaptor molecule that is capable of caspase-8 recruitment and activation. Apoptosis is either induced through direct caspase-8-mediated caspase-3 activation or through an amplification loop involving the mitochondria and the cleavage of the $\mathrm{BH}$-only protein Bid by caspase-8, cFLIP interferes with the generation of active caspase-8, attenuating the role of DISC. Adapted from Naoum et al., 2016. ${ }^{34}$ 
tuted with Bax was markedly higher. ${ }^{49}$ It has been reported that combining TRAIL with radiation or chemotherapy can overcome TRAIL resistance by Bax overexpression. ${ }^{4,50,51}$

$\mathrm{NF}-\kappa \mathrm{B}$ another factor that may exert protection against cell death through upregulation of XIAP, FLIP and Bcl-X $\mathrm{X}_{\mathrm{L}}$. In addition, TRAIL sensitivity can be significantly restored by specific downregulation of $\mathrm{NF} \kappa \mathrm{B}$ through inactivation of $\mathrm{I}-\kappa \mathrm{B}$ kinase. ${ }^{52}$

Interestingly the downstream target of the NF- $\kappa B$ pathway, the transcription factor SNAIL, can play a role in TRAIL sensitivity. It was shown that silencing the expression of SNAIL can potentiates the TRAIL induced apoptosis by p53 upregulation and downregulation of Bcl- $\mathrm{X}_{\mathrm{L}}$, survivin and Raf-1 of the NF- $\mathrm{KB}$ pathway. ${ }^{53}$

\section{Translation of the molecular biology to cancer clinical therapy}

\section{Why trail for cancer}

Since the identification of chemotherapy and radiotherapy as efficacious implements for cancer treatment, the two main quandaries were the resistance of malignant cells to these implements and the toxicity to normal body cells. This explicates the medical society excitement upon revelation of TRAIL mechanism and the high expectations scientists had for it.
TRAIL pathway raised as an attractive therapeutic target for cancer due to its ability to target tumor cells with no/minimal effects on normal cells, this principle was tested by Walczak et al. when histological examination of tumors from mice treated with LZ-huTRAIL demonstrated clear areas of apoptotic necrosis within 9-12 hours of injection with no toxicity to normal tissues. ${ }^{54}$ The safety of TRAIL preparations was further attested by consequential number of phase I trials as shown later.

One of the proposed mechanisms for this selective cytotoxicity and the resistance of normal cells to TRAIL induced apoptosis is that TRAIL death receptors (TRAILR- 1/DR4 and R-2/DR5) are strongly expressed in malignant cells, as mentioned earlier, while its decoy receptors (TRAILR-3/DcR1, TRAILR-4/DcR2) are strongly expressed in normal cells.

In 2006 a study assessed TRAIL-R1 and TRAIL-R2 expression patterns in a large cohort of melanomas in comparison to benign nevi concluded that TRAIL-R1 and TRAIL-R2 expression was higher in malignant melanocytes than in their benign counterparts. ${ }^{55}$

Another advantage of TRAIL over chemotherapy or radiotherapy is its ability to induce apoptosis regardless of the tumor protein p53 status. Mutation of p53 gene is known to be one of the initial events in oncogenesis and one of mechanism in chemotherapy resistance ${ }^{56}$ as most conventional chemotherapy and radiotherapy induce their antitumor activity through p53 dependent manner. Inactivation of p53, either directly through TP53 mutations or indi-

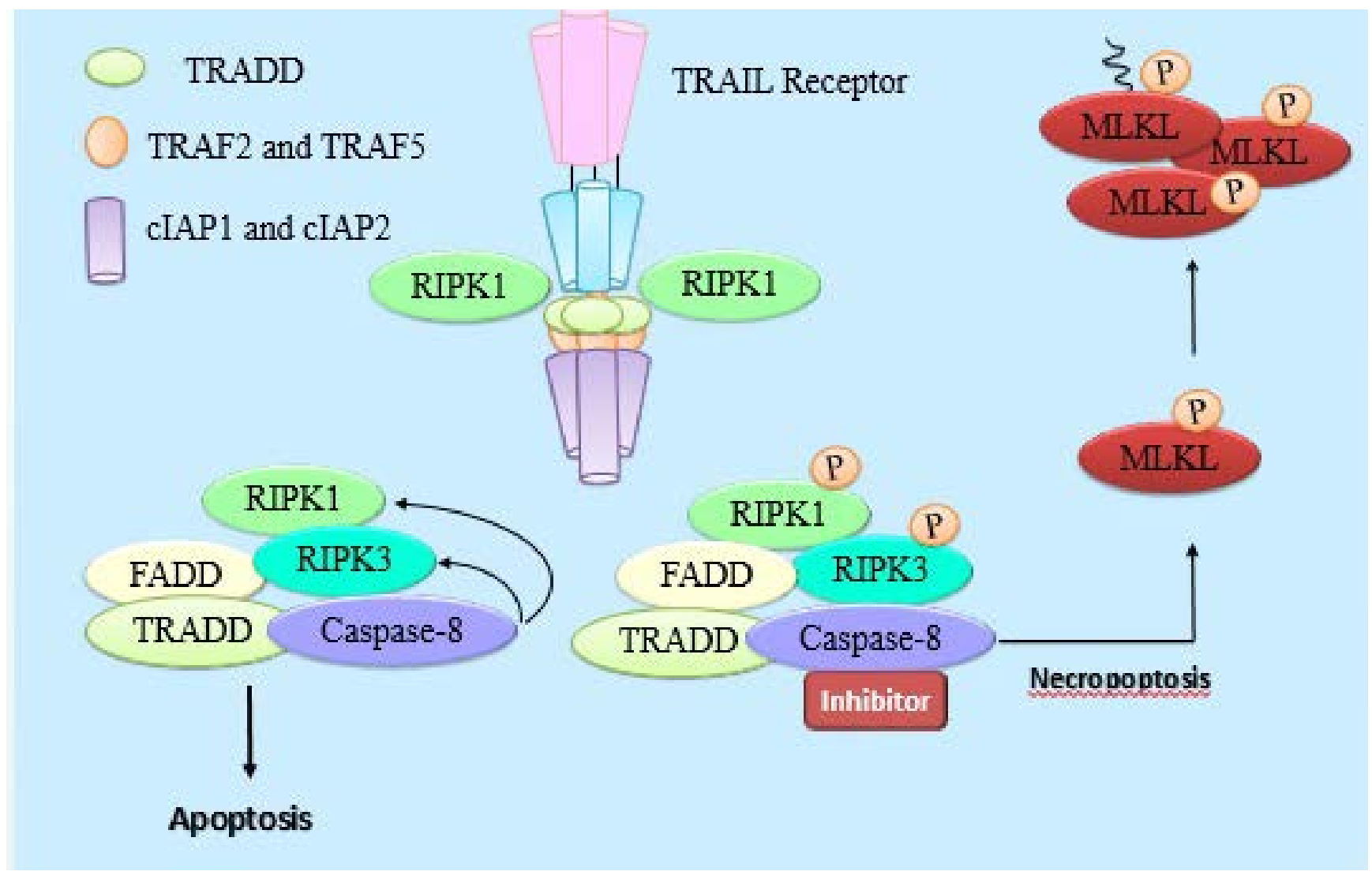

Figure 2. Summary of proteins and molecules involved in TRAIL induced necroptosis. Activation of RIPK1 and RIPK3 subsequently results in phosphorylation of mixed lineage kinase domain-like protein (MLKL), then they contribute to its trimerization, leading to necroptosis. 
rectly through $\mathrm{p} 53$ modulators such as the MDM2 protein, occurs in many human cancers. Without proper p53 function, tumor cells escape apoptosis and continue to proliferate, despite the genetic instabilities induced by chemotherapy or irradiation. ${ }^{28}$

TRAIL on the other hand circumvents this problem by inducing both the extrinsic and the intrinsic cell death pathways upon binding to his receptors without dependence on p53. Thus serving as a useful agent particularly in cells in which p53-responsive pathway has been inactivated.

Adding to that many preclinical studies have shown that adding TRAIL to chemotherapy or ionizing irradiation increased apoptosis in cancer cells. ${ }^{57-59}$ This combinatorial approach induced synergism will help in decreasing the dose of chemoradiotherapy and their off-target effects in clinical field. Many studies have proposed different molecular mechanisms for this synergism. Among these mechanisms; Direct Inhibition of anti apoptotic factors like surviving and NF- $\mathrm{BB}$, upregulating of DR-5 and downregulation of decoy receptors expression DcR2, increasing the activity of Caspase- 8 and Caspase-9, and finally increasing the pro apoptotic proteins like Bax. ${ }^{60-68}$

The role of TRAIL in necroptosis, described earlier, opens the door for development of TRAIL based medications, to activate such pathway especially in cancer cells resistant to apoptosis.

Last but not least TRAIL was found to affect Cancer stem cells (CSCs). Higher expression of death receptors was noted in glioblastoma and lung $\mathrm{CSCs}^{69}$ and responsiveness of colon CSCs to TRAIL was much better. ${ }^{70}$ These facts highlighted TRAIL as a potent anticancer agent against CSCs. Adding to that it was demonstrated that TRAIL could interfere and interrupt with CSCs self renewal pathways; Wnt, Hedgehog and Notch. ${ }^{34,71-74}$

The interest for use of TRAIL as cancer cytotoxic agent was initially met with careful optimism. This was due to previous experience with usage of systemic TNF that resulted in significant toxicities. ${ }^{75,76}$ This was followed by the discovery of agonistic antibodies targeting DR FAS/APO-1 (CD95) but unfortunately the systemic treatment with recombinant CD95L or CD95-agonistic antibodies resulted in fulminant and lethal hepatotoxicity. ${ }^{77,78}$

On the contrary TRAIL preparations have proved excellent safety profile through phase I trials and were generally well tolerated by most of the patients. ${ }^{79,80}$ All these advantages highlight the unique features of TRAIL as a cancer cytotoxic agent and propose it as the future molecule in eliminating recurrence and metastasis through the necroptosis properties and interactions with cancer stem cells. Therefore many preparations have been designed for introduction in clinical field.

\section{TRAIL preparation for clinical usages}

A variety of forms of human recombinant soluble TRAIL have been developed. They are known to exhibit their actions by encoding the extracellular domain of human TRAIL. Some preparations are fused on their amino-terminal sequence to different tags such as the polyhistidine tag, ${ }^{81}$ FLAG epitope ${ }^{82}$ and IZ (isoleucine zipper) trimerisation domains. ${ }^{83}$ Some studies showed that TRAIL could be a cytotoxic agent due to its ability to kill in vitro normal cells including primary hepatocytes, keratinocytes and astrocytes. ${ }^{84-86}$ A preparation of TRAIL lacking sequence modifications to amino acids 114-281 and with the addition of a modified leucine zipper produced tumor cytotoxicity in vitro and tumor growth inhibition in vivo without hepatotoxicity and significant tumor penetration as well. ${ }^{79,87}$ This version of TRAIL, also known as (AMG951) or APO2L/TRAIL or dulanermin was produced by Genentech as the first the first human recombinant TRAIL preparation.

Another TRAIL preparation named CPT, ${ }^{88}$ has been used in clinical trials. Its unique structure lies in fusing human TRAIL amino acid residues $135-280$ (C terminus) to residues $122-135$ (N terminus) by a flexible linker. Like TRAIL, the anti-tumoral effects of CPT on several tumour types was demonstrated either alone or with chemotherapeutic agents in preclinical studies testing CPT demonstrated its anti-tumoral characteristics alone and in association with chemotherapy. ${ }^{89-91}$

In addition to the fact that previous versions of TRAIL were found to have short half-life, it was suggested that if some tumor cells are protected from rTRAIL-induced apoptosis through expression of decoy receptors. Therefore, specific targeting of death receptors by agonistic antibodies may be more effective to eliminate these tumor cells

Griffith et al., immunized BALB/c mice with several soluble fusion proteins containing the extracellular portion of each human TRAIL receptor (TRAIL-R1/DR4, -R2/DR5, -R3/DcR1, or R4/DcR2) coupled to the Fc domain of human IgG1. Using the generated murine MoABs, they have demonstrated that either antiDR4 or anti-DR5 can promote apoptosis in TRAIL-sensitive melanoma cell lines, while anti-TRAIL-R3/R4 could not. ${ }^{92}$

Other than their killing ability, Takeda et al. were able to demonstrate the capability of DR5 MoAb (MD5-1) to trigger FcR dependent cytolysis of tumor cells in vitro. This cytotoxic effect was not mediated only through DR5 mediated caspase cell death but also through caspase independent antibody-dependent cellmediated pathway. MD5-1 was able to induce apoptosis by recruiting FcR-expressing macrophages and was also capable of targeting the apoptotic tumor cells to the antigen presenting cells via FcR. Then, the APCs cross-present tumor antigens and induce tumorspecific cytotoxic T lymphocytes.

Testing the above mechanism, MD5-1 administration afforded complete rejection of low doses of mammary carcinoma cells (4T1 cells) in wild-type BALB/c mice. When mice were rechalenged with 4T1 cells complete rejection was noticed.

The transfer of splenic T cells isolated from wild-type BALB/c mice that had rejected cells after MD5-1 treatment, protected another strain of mice from a lethal dose of 4T1 tumor challenge.

These results suggested that DR5 might be a potential potent anticancerous agent that can be used not only to eliminate TRAILsensitive tumor cells temporarily, but will be able to offer protection against tumor recurrence as well. ${ }^{93,94}$

Ichikawa et al. have reported a murine MoAb targeting human DR5 (TRA-8). ${ }^{95}$ This was generated by immunizing BALB/c mice with DR5-IgG1 fusion protein containing the extracellular domain of human DR5 (aa 1-180) and the Fc portion of human IgG1. TRA8 induced apoptosis in most rTRAIL-sensitive tumor cell lines and effectively reduced tumor growth in xenografted mice. Also this anti-DR5 MoAb did not react with, or induce apoptosis in, freshly prepared normal human hepatocytes in vitro. ${ }^{95}$ Other DR5 MoAB than TRA- 8 have been developed, these include the Human Genome Science (HGS) fully human antibodies (HGS-ETR2 and HGS-TR2J anti-DR5), the Novartis LBY135 anti-DR5 antibodies, Genentech Apomab fully human anti-DR5 antibody, and the Amgen AMG 655.

It has been experimentally verified that murine MoAbs against human DR4 could induced apoptosis in rTRAIL-sensitive tumor cell lines, however TRAIL treated DR4-expressing normal human endothelial cells did not undergo apoptosis. ${ }^{96}$ Many preclinical studies have reported different types of anti DR-4. However, the only one that was available for clinical usage was the Human Genome Science (HGS) fully human antibody HGS-ETR $1^{97}$ later on known as Mapatumumab.

In the following part we are going to discuss the clinical trials that have tested these preparations targeting TRAIL. 


\section{Clinical trials: soluble TRAIL}

Dulanermin was tested on patients having metastatic or advanced solid tumors in phase Ia studies and reported that it can be safely administered intravenously up to $30 \mathrm{mg} \cdot \mathrm{kg}^{-1}$ with a $1 \mathrm{~h}$ elimination half-life. ${ }^{98}$ The peak plasmatic concentrations at 0.5 and $30 \mathrm{mg} \cdot \mathrm{kg}^{-1}$ administration doses was found to be varying from 5 to $220 \mu \mathrm{g} \cdot \mathrm{mL}^{-1}$ respectively. The reported side effects included nausea, fatigue, fever, vomiting, constipation and anemia. However, 33 patients showed stable disease, 5 showed partial response 2 of them are patients with chondrosarcoma who showed clinical anti-tumor activity after being treated with dulanermin for 2-3 years. Xin et al. reported in 2008 that pharmacokinetic parameters of dulanermin are not affected by gender, race or even enzymatic activities such as AST or ALP from phase Ia trial on 67 patients.

Cytotoxic effects of TRAIL in combination with either conventional or targeted anticancer therapeutics with dulanermin are currently being tested in clinical trials as depicted in (Table 1). ${ }^{99}$ 105 However, the results of these combinations, despite being well tolerated, did not meet the expectations in improving overall survival and response.

Chen et al. in 2012 used CPT on 27 patients with refractory or relapsed multiple myeloma. ${ }^{106}$ They have reported from the phase $\mathrm{Ib}$ of their study that it is safe and tolerated up to $15 \mathrm{mg} \cdot \mathrm{kg}^{-1}$ intra- venously with a $1 \mathrm{~h}$ half-life like dulanermin. Also complete response was noted in one patient while four patients achieved partial responses. However, $33 \%$ overall response rate was reported in the phase II of this study with complete response achieved in one patient and partial response in eight patients. ${ }^{107}$ Also, they reported three patients experiencing severe side effects (one of them with CPT-related liver injury). However, a combination of CPT with thalidomide, was reported to be well tolerated and with superior tumoral cytotoxic effects in patients suffering refractory or relapsed multiple myeloma who failed to respond to thalidomide alone. ${ }^{108}$

\section{Monoclonal antibody targeting TRAIL receptors}

\section{Anti-DR4 agonistic monoclonal antibody}

Mapatumumab, also called HGS-ETR1 or TRM1 is so far the only monoclonal antibody tested for efficacy in clinical trials. Pucak et al. ${ }^{97}$ were the first to clone Mapatumumab through single chain variable fragment $(\mathrm{scFv})$ technology as a fully human anti DR4 antibody. They successfully showed high cytotoxic efficiency of HGS-ETR1 to various cancer cell lines expressing DR4, through high biding affinity to this receptor, with no cross binding

Table 1. Summary of clinical trials using dulanermin in combination with chemotherapy.

\begin{tabular}{|c|c|c|c|c|}
\hline $\begin{array}{l}\text { Combination of } \\
\text { Dulanermin or } \\
\text { AMG951 with }\end{array}$ & Study population & Safety & Best response & nce or Trial number \\
\hline Rituximab & $\begin{array}{l}7 \text { patients with } \\
\text { Low-grade non-Hodgkin } \\
\text { lymphoma } \\
48 \text { patients with } \\
\text { Low-grade } \\
\text { non-Hodgkin lymphoma }\end{array}$ & $\begin{array}{l}\text { Combination appears safe } \\
\text { and shows evidence of activity } \\
\text { Not better than } \\
\text { rituximab alone }\end{array}$ & $\begin{array}{l}\text { Complete response (2), } \\
\text { partial response (1), } \\
\text { stable disease (1) }\end{array}$ & NCT00400764 \\
\hline \multirow[t]{2}{*}{$\begin{array}{l}\text { Carboplatin, paclitaxel } \\
\text { and bevacizumab }\end{array}$} & $\begin{array}{l}24 \text { patients with } \\
\text { Advanced tumours }\end{array}$ & $\begin{array}{l}\text { Dulanermin plus paclitaxel, } \\
\text { carboplatin, bevacizumab } \\
\text { was well tolerated with no } \\
\text { occurrence of dose-limiting } \\
\text { toxicity }\end{array}$ & $\begin{array}{l}\text { Complete response (1), } \\
\text { partial response (13), } \\
\text { stable disease (9) }\end{array}$ & 99 \\
\hline & $\begin{array}{l}213 \text { patients with Untreated } \\
\text { advanced stage IIIb/IV } \\
\text { non-small cell lung } \\
\text { carcinoma }\end{array}$ & $\begin{array}{l}\text { Not better than paclitaxel, } \\
\text { carboplatin, or paclitaxel, } \\
\text { carboplatin, bevacizumab } \\
\text { pharmacokinetics appeared } \\
\text { unaltered }\end{array}$ & - & $\begin{array}{c}100 \\
\text { NCT00508625 }\end{array}$ \\
\hline FOLFOX bevacuzimab & $\begin{array}{l}23 \text { patients with Untreated, } \\
\text { locally advanced, recurrent, } \\
\text { or metastatic colorectal cancer }\end{array}$ & No adverse interactions & $\begin{array}{l}\text { Partial response }\left(12 \pm 3^{*}\right) \text {, } \\
\text { Stable disease }(7)\end{array}$ & NCT00873756 \\
\hline AMG479 (anti-IGFR1) & $\begin{array}{l}89 \text { patients with Advanced } \\
\text { refractory solid tumours } \\
\text { (non-small cell lung carcinoma, } \\
\text { colorectal cancer, pancreatic } \\
\text { ovarian and sarcomas) }\end{array}$ & Not reported & Terminated & NCT00819169 \\
\hline $\begin{array}{l}\text { Irinotecan and cetuximab } \\
\text { or FOLFIRI }\end{array}$ & $\begin{array}{l}30 \text { patients with metastatic } \\
\text { colorectal cancer }\end{array}$ & Safe with irinotecan-regimen & Not reported & 104 \\
\hline $\begin{array}{l}\text { Camptosar and Erbitux } \\
\text { or FOLFIRI w/o } \\
\text { bevacizumab }\end{array}$ & $\begin{array}{l}\text { Previously treated metastatic } \\
\text { colorectal cancer } \\
\text { (no available data about } \\
\text { number of patient) }\end{array}$ & Not reported & Ongoing, not recruiting & NCT00671372 \\
\hline $\begin{array}{l}\text { FOLFIRI with or } \\
\text { without bevacuzimab }\end{array}$ & $\begin{array}{l}27 \text { patients with Previously } \\
\text { treated metastatic colorectal } \\
\text { cancer }\end{array}$ & $\begin{array}{l}\text { Safe with FOLFIRI } \\
\text { ( } \pm \text { bevacuzimab) }\end{array}$ & $\begin{array}{l}\text { Partial response (6), } \\
\text { stable disease (17) }\end{array}$ & 105 \\
\hline
\end{tabular}


to DR5. Interestingly, it was concluded that decoy receptors were not a resistance factor to Mapatumumab due to this selective binding properties. ${ }^{97}$ These results led Human Genome Sciences, Galaxo SmithKline and Takeda to develop HGS-ETR1 for commercial usages and testing. Mapatumumab has been assessed against different types of tumors in phase I and II clinical trials either alone or in combination with chemotherapy as depicted in (Table 2). ${ }^{103,109-117}$

\section{Anti-DR5 agonistic monoclonal antibodies}

TRAIL-R2/DR5 agonistic monoclonal antibodies, have been designed and generated more than the ones targeting TRAILR1/DR4. In the following part of this review we are going to discuss 5 of these MoAb that have been assessed either alone or with chemotherapy in clinical trials. These are Tigatuzumab (CS-1008 or TRA-8), Conatumumab (AMG655), LBY135, Drozitumumab (Apomab or PRO95780) and Lexatumumab (HGS-TR2).

Table 2. Showing clinical trials of Mapatumumb either alone or in combinational approaches

\begin{tabular}{|c|c|c|c|c|c|c|}
\hline Drug used & Phase & $\begin{array}{l}\text { Pts No. } \\
(=)\end{array}$ & $\begin{array}{l}\text { Study } \\
\text { population }\end{array}$ & Safety & Best response & $\begin{array}{l}\text { Reference or } \\
\text { Trial number }\end{array}$ \\
\hline \multicolumn{7}{|c|}{ Combination of Mapatumumab with } \\
\hline \multirow[t]{2}{*}{$\begin{array}{l}\text { Paclitaxel and } \\
\text { carboplatin }\end{array}$} & I & 27 & $\begin{array}{l}\text { Advanced solid } \\
\text { tumours }\end{array}$ & $\begin{array}{l}\text { Safe with paclitaxel } \\
\text { and cisplatin up to } 20 \mathrm{mg} \cdot \mathrm{kg}^{-1} \\
\text { with no occurrence of dose } \\
\text { limiting toxicity }\end{array}$ & $\begin{array}{l}\text { Partial response (5), } \\
\text { stable disease (12) }\end{array}$ & 109 \\
\hline & $\mathrm{Ib}$ & 28 & $\begin{array}{l}\text { Advanced solid } \\
\text { tumours }\end{array}$ & $\begin{array}{l}\text { Pharmacokinetic profile } \\
\text { of HGS-ETR1 not affected } \\
\text { by paclitaxel and carboplatin }\end{array}$ & $\begin{array}{l}\text { Partial response (6), } \\
\text { stable disease }^{103}\end{array}$ & 109 \\
\hline $\begin{array}{l}\text { Paclitaxel and } \\
\text { carboplatin }\end{array}$ & II R & 111 & $\begin{array}{l}\text { First-line advanced } \\
\text { non-small cell lung } \\
\text { carcinoma }\end{array}$ & $\begin{array}{l}\text { The results do not support } \\
\text { further evaluation } \\
\text { in combination with paclitaxel, } \\
\text { carboplatin in patients with } \\
\text { advanced non-small cell lung } \\
\text { carcinoma }\end{array}$ & $\begin{array}{l}\text { Similar to paclitaxel, } \\
\text { carboplatin alone }\end{array}$ & $\begin{array}{c}110 \\
\text { NCT00583830 }\end{array}$ \\
\hline $\begin{array}{l}\text { Gemcitabine } \\
\text { and cisplatin }\end{array}$ & $\mathrm{Ib}$ & 49 & Advanced solid tumours & $\begin{array}{l}\text { Safe with gemcitabine and } \\
\text { cisplatin at doses up } \\
\text { to } 30 \mathrm{mg} \cdot \mathrm{kg}^{-1}\end{array}$ & $\begin{array}{l}\text { Partial response (12), } \\
\text { stable disease }^{111}\end{array}$ & 112 \\
\hline $\begin{array}{l}\text { Cisplatin and } \\
\text { radiotherapy }\end{array}$ & $\mathrm{Ib} / \mathrm{II}$ & $42^{*}$ & $\begin{array}{l}\text { Objective is } 42 \\
\text { Patient with first-line } \\
\text { advanced cervical cancer }\end{array}$ & Recruiting & Not reported & NCT01088347 \\
\hline \multirow[t]{2}{*}{ Sorafenib } & $\mathrm{Ib}$ & 19 & $\begin{array}{l}\text { Advanced hepatocellular } \\
\text { carcinoma and chronic } \\
\text { viral hepatitis }\end{array}$ & $\begin{array}{l}\text { Safe with sorafenib at } \\
\text { doses up to } 30 \mathrm{mg} \cdot \mathrm{kg}^{-1}\end{array}$ & $\begin{array}{l}\text { Partial response (2), } \\
\text { stable disease (4) }\end{array}$ & NCT00712855 \\
\hline & II & $100^{*}$ & $\begin{array}{l}101 \text { patients were randomized; } \\
51 \text { in the placebo-sorafenib } \\
\text { arm and } 50 \text { patients in the } \\
\text { mapatumumab- } \\
\text { sorafenib arm }\end{array}$ & $\begin{array}{l}\text { Overall, the frequency of AEs, } \\
\text { serious AEs (SAEs), } \\
\text { and severe AEs was comparable } \\
\text { between the two treatment arms. } \\
\text { Only increased lipase was } \\
\text { considered related to } \\
\text { mapatumumab by investigators. }\end{array}$ & $\begin{array}{l}\text { NO clinical or statistical } \\
\text { significance were } \\
\text { noted between } \\
\text { the } 2 \text { arms in } \\
\text { terms of median } \\
\text { PFS or median OS }\end{array}$ & NCT01258608 \\
\hline
\end{tabular}

\begin{tabular}{|c|c|c|c|c|c|c|}
\hline Bortezomib & II R & 104 & $\begin{array}{l}\text { Relapsed/ } \\
\text { Refractory multiple myeloma }\end{array}$ & No adverse effects but no benefit & $\begin{array}{l}\text { Similar to } \\
\text { bortezomib alone }\end{array}$ & NCT00315757 \\
\hline \multicolumn{7}{|c|}{ Mapatumumab or TRM1 or HGS-ETR1 alone } \\
\hline & Ia & 49 & Advanced solid tumours & $\begin{array}{l}\text { Safe and well tolerated up to } \\
20 \mathrm{mg}^{-1} \mathrm{~kg}^{-1} \text { i.v. } \\
\text { - half-life 18-21 days }\end{array}$ & Stable disease (19) & 113 \\
\hline & la & 41 & Advanced solid tumours & $\begin{array}{l}\text { Peak plasmatic concentrations } \\
\text { compatible with preclinical studies }\end{array}$ & Stable disease (12) & 114 \\
\hline & $\mathrm{Ib} / \mathrm{II}$ & 40 & $\begin{array}{l}\text { Relapsed/Refractory } \\
\text { non-Hodgkin lymphoma }\end{array}$ & $\begin{array}{l}\text { Three clinical responses out of } 15 \\
\text { follicular lymphoma patients. }\end{array}$ & $\begin{array}{l}\text { Complete response (2), } \\
\text { partial response (1), } \\
\text { stable disease (12) }\end{array}$ & $\begin{array}{c}115 \\
\text { NCT00094848 }\end{array}$ \\
\hline & II & 32 & $\begin{array}{l}\text { Relapsed/Refractory } \\
\text { stage IIIb/IV or } \\
\text { recurrent non-small } \\
\text { cell lung carcinoma }\end{array}$ & $\begin{array}{l}\text { No adverse effects, } \\
\text { but no clinical activity } \\
\text { demonstrated }\end{array}$ & Stable disease (9) & $\begin{array}{c}116 \\
\text { NCT00092924 }\end{array}$ \\
\hline & II & 38 & Refractory colorectal cancer & - & Stable disease (12) & 117 \\
\hline
\end{tabular}

*Estimation/expected. Clinical trials number listed in this table can be found at: http://www.clinicaltrials.gov 


\section{Tigatuzumab}

In 2010 Forero-Torres et al. reported effectiveness of Tigatuzumab in patients suffering refractory or relapsed lymphoma or solid tumors. ${ }^{118}$ Out of 17 patients previously treated with chemotherapy enrolled 7 showed stable disease. One progressive metastatic hepatocellular carcinoma patient, who failed to respond to different chemotherapy drugs and suffered pain, became pain free after 6 weeks of Tigatuzumumab therapy onset and remained asymptomatic for more than 26 months. They also reported Tigatuzumab to be tolerated up to $8 \mathrm{mg} \cdot \mathrm{kg}^{-1} /$ day with no dose limiting toxicity and an approximate T1/2 (half-life) of 6-10 days. However, it was reported that TR-8 did not improve efficacy of carboplatin/paclitaxel in systemic therapy-naïve for unselected advanced NSCLC ${ }^{119}$ patients in a randomized double blind placebo controlled phase 2 study. In this study Tigatuzumab was also found to be well tolerated in general. ${ }^{120}$ Anyway, 10 patients developed grade $3 / 4$ neutropenia in tigatuzumab arm versus 4 patients in placebo arm.

Other clinical trials combining TR-8 with different chemotherapy drugs in different tumor types have been completed but their results are not yet reported. ${ }^{121}$

\section{Conatumumab (AMG 655)}

Conatumumab proved to be effective against advanced solid tumors. ${ }^{122,123}$-However, the response to combination of chemotherapy with Conatumumab was found varying according to the combining agent. Cohn et al. tested the combination of Conatumumab with FOLFIRI or with ganitumab + FOLFIRI as second line in treatment of mutant KRAS mCRC. ${ }^{124}$ They reported that Conatumumab plus FOLFIRI, but not ganitumab was associated with a progression in free survival. However, acceptable manageable toxicity of both combination with neutropenia and diarrhea as the most common grade $\geq 3$ adverse events was reported. Chawla et al. ${ }^{125}$ reported its clinical activity in combination with an anti-IGFR1 MoAB (Ganitumab) in patients with advanced refractory solid tumors and to be tolerated up to $15 \mathrm{mg} / \mathrm{kg}$. The addition of conatumumab to Gemcitabine resulted in trends toward longer Performance Free Survival, improved 6-months overall survival, and higher rates of stable disease in patients having metastatic pancreatic cancer. ${ }^{126} \mathrm{On}$ the other hand a combination of Conatumumab with carboplatin and paclitaxel as first line for treatment of NSCLC, ${ }^{127}$ with Panitumumab in metastatic colorectal cancer ${ }^{128}$ or with Doxorubicin in unrespectable soft tissue sarcoma all were found to be not effective despite being well tolerated.

\section{Drozitumab}

So far, Drozitumab alone failed to show objective response in patients with advanced solid tumors. However, It was reported minor responses in three patients with granulosa cell ovarian cancers, colorectal and chondrosarcoma. ${ }^{129}$ Disappointing results were also reported with combined studies. In association with paclitaxel, bevacizumab and carboplatin in stage IIIb and IV previously untreated NSCLC patients ${ }^{130}$ or with rituximab for patients suffering from relapsed non-Hodgkin's lymphoma ${ }^{131}$ drozitumab failed to exert any clinical activity. Minor antitumor activity has been noticed from using drozitumab with Cetuximab and irinotecan or FOLFIRI with or without bevacuzimab ${ }^{132}$ or FOLFOX with or without bevacizumab ${ }^{133}$ as first-line treatment of metastatic colorectal cancer patients. It is also to be noted that at the time of writing this review no ongoing trials with drozitumab were found.

\section{LBY135}

Sharma et al. ${ }^{134}$ assessed LBY135 alone or with association with capecitabin in patients with advanced solid tumors. It was shown to be tolerated and safe up to $20 \mathrm{mg} \cdot \mathrm{kg}^{-1}$. From this phase 1 trial, minor response was reported on one patient with sarcoma and two patients with NSCLC and prostate cancer had tumor markers decrease of $50 \%$ and $40 \%$ respectively. When combined with capecitabin, LBY135 induced 60-73\% tumor mass reduction in four patients with ovarian, pancreatic and colorectal cancers and two ovarian and colorectal cancer patients partially responded.

\section{Lexatumumab}

Unlike other members of its family, few clinical studies assessing the toxicity of Lexatumumab either alone or with chemotherapy combination. However it was found to be effective alone against advanced solid tumours ${ }^{135}$ and lymphomas. ${ }^{136}$ The most striking effect was reported from a pediatric solid tumours study ${ }^{137}$ where a teenager with progressive, lung/chest wall osteosarcoma, achieved complete response and remained symptoms free after 2 years lexatumumab treatment. Minor tumor shrinkage from combining lexatumumab with FOLFIRI and doxorubicin in advanced solid tumors was reported as well. ${ }^{138}$

Unfortunately randomized Phase II studies have not demonstrated strong clinical activity, and no death receptor agonist therapies have advanced into Phase III.

An explanation of such poor clinical efficacy is the crosslinking requirements or pharmacokinetics of these monoclonal antibodies. This is due to the fact that for efficient apoptosis induction via DRs their trimerization is required. ${ }^{139}$

Therefore, trials have continued in the past decade to create more tumoricidal and potent TRAIL based designs.

\section{Recent advances in TRAIL therapies designs and potential role in immuno-oncology}

\section{Recent drug delivery designs for TRAIL}

TR3, a fusion protein formed by 3 covalently linked TRAIL ectodomains is noted be an effective agent. Furthermore, insertion of the 64 amino acid mesothelin-encoding cDNA into the 5 '-terminal of TR3 expression platform made it more selective. ${ }^{140-142}$ It is also to be noted that, mesothelin is a frequently overexpressed tumor biomarker in different malignancies paving the path towards more enhanced targeted therapy. TR3 interacted with MUC16overexpressing cancer cells and Meso64-TR3 considerably reduced growth of the tumor in mice inoculated subcutaneously with ovarian cancer cells. ${ }^{142}$ Tatzel et al. recently showed an important piece of evidence in the design of recombinant TR 3 therapeutics. ${ }^{143}$ Using SS-TR3 (a TR3 targeting mesothelin) they showed that juxtapositioning of TR3-based drug to the membrane of its intended target triggered a repulsive force between the ligand and its receptor due to equivalent polarities between TR3 and DR5. ${ }^{143}$ Therefore, insertion of a spacer into the Mesothelin target antigen (Meso/DAF) or into the TR3-cancer drug itself (SS-STR3) leads to restoration of the reciprocal polarities with subsequent physical attraction and conversion of SS-TR3 into a cis-acting biologic weapon. This discovery may have a clinical impact on choosing the suitable drug. For example, if circulating tumor cells are to be targeted, the cis acting TR3 (spacer-containing TR3) seemingly proved to be the therapeutic agent of choice. Whereas, if solid tumors are the target, the spacer-deficient drugs may prove to be more effective because of smaller size, better penetrance in tissues and the ability to induce bystander cell death. ${ }^{143}$

An amazing combinatorial targeted immunotherapy approach, 
was recently achieved through designing a bi-functional fusion protein containing PD-L1-blocking antibody fragment genetically fused to the extracellular domain of TRAIL. ${ }^{144}$ This anti-PDL1:TRAIL fusion protein induced cell death in PD-L1 expressing tumor cells and augmented $\mathrm{T}$ cell activity, proliferation and secretion of IFN $\gamma$. The increased levels of IFN $\gamma$ simultaneously increased PD-L1 expression in cancer cells and sensitized them to the apoptotic effects induced by anti-PD-L1:TRAIL. ${ }^{144}$ Such types of designs offer multifold reinforced anticancer activity.

Another combinatorial immunotherapy approach with TRAIL was achieved through designing secretory TRAIL-armed natural killer (NK) cell. A lentiviral vector consisting of a trimerization domain, a secretion signal domain, and an extracellular domain of the TRAIL gene was used to transduce NK cells so they can secrete glycosylated form of TRAIL. These genetically engineered NK were able to induce apoptosis when injected intraperitoneally posing a new potential for peritoneal carcinomatosis treatment. ${ }^{145}$

Albumin, a protein abundantly found in plasma has a half-life of 3 weeks mainly by courtesy of its size and escape from intracellular degradation because of FcRn-mediated recycling. Human serum albumin (HSA) has a longer half-life of 19 days approximately. Moreover, albumin is intrinsically capable of extravasation and accumulation in tumor mass. A 46-amino acid albumin-binding domain (ABD) derived from streptococcal protein $\mathrm{G}$ has been shown to demonstrate higher (femto-molar to nano-molar) affinity for human albumin. ABD genetically fused to the amino terminal or Carboxyl-terminal of TRAIL was tested for efficacy and impact of the ABD-fusion on circulatory half-life and albumin binding. ABDfused TRAIL was intravenously administered in mice bearing subcutaneous tumor xenografts and results revealed marked inhibition of tumor growth. Circulating tumor cells (CTC) elimination notably reduced the chances of secondary lung cancer development. Because of the longer circulatory half-life of ABD fused TRAIL, ABD-TRAIL mediated killing of CTC was significantly longer as evidenced by remarkably reduced secondary lung cancer development. ${ }^{146}$

Exosomes are cell-derived vesicles originating from invagination of the limiting membrane of endosomes, through pathways depending on the cell type and cargo. TRAIL-expressing exosomes have been generated by initial transduction of K562 cells with TRAIL expressing lentiviral vector and sequential ultracentrifugation. They showed homing to tumor sites and significant reduction in tumor growth SCID mice. ${ }^{147}$

\section{Single-chain variable-fragment (scFv) domains target- ing TRAIL pathway}

Another option to target TRAIL receptors is the scFv (Singlechain variable-fragment) domains. These agents are advantageous in terms of maintenance of antigen specificity of full immunoglobulins, having a size of $25 \mathrm{kDa}$ and can significantly fuse with TRAIL. ${ }^{148-150}$

Wang et al. were able to generate an Fc-TRAIL fusion protein through fusion of TRAIL to the Fc portion of human IgG1 and were able to demonstrate that its activity was enhanced by approximately $30 \%$ compared with rh-TRAIL in two cell lines in vitro, This enhanced activity is likely due to the homodimeric nature of Fc because TRAIL activates its signaling by inducing oligomerization of TRAIL receptors on the cell surface. Moreover, Fc-TRAIL displayed higher affinity to DR5 than rh-TRAIL and the cell killing activity was sustained for more than 12 hours following a single injection of Fc-TRAIL without significant toxicity. ${ }^{140}$

One of the promising techniques is the usage of chimeric antigen receptor (CAR) expressing T cells to target TR1 receptors, this was accomplished using a CAR of a TR1-specific scFv antibody (TR1-scFv-CAR) with the aim of inducing efficient trimerization of TR1 with cell surface TR1-scFv-CAR, leading to apoptosis induction in tumor cells. It was found that the TR1-scFvCARexpressing NK cell line and peripheral blood lymphocytes killed target cells via CAR signal- induced cytolytic activity in addition to TR1-induced apoptosis. ${ }^{141}$

A promissing startegy for targeted therapy, is using $\mathrm{scFv}$ loaded with TRAIL that specifically targets surface antigens highly expressed by cells of certain tumor types. Many constructs of scFv:TRAIL have been designed to target several of these antigens.

A scFv425:sTRAIL actively targeting EGFR, has showed increased drug bioavailability with enhanced cytotoxic activity, and no remarkable side effects in xenograft models. ${ }^{151,152}$

Various cluster of differentiation ${ }^{14}$ have been actively targeted with scFv loaded with TRAIL as illustrated in Table 3. ${ }^{153-158}$

Interestingly scFv targeting TRAIL receptors not only showed apoptotic effects but also induced autophagy in both TRAIL sensitive and resistant cells. HW1 a scFv targeting DR5 induced autophagy predominantly via caspase-independent JNK activation. Such approach offers a promising platform for non-apoptotic elimination of TRAIL resistant tumor cells. ${ }^{159}$

Recently in 2016 Siegemund et al. designed a bioactive

Table 3. Showing variable designs of scFv targeting TRAIL receptors.

\begin{tabular}{|c|c|c|c|}
\hline Designed molecule name & Target & Main effects & Ref. \\
\hline scFvCD19:sTRAIL & CD19 & $\begin{array}{l}\text { 1. Absence of side effects } \\
\text { 2. Increased antitumor activity against: } \\
\text { A) Hematologic tumor cell lines and B-CLL primary cells in vitro } \\
\text { B) Tumor xenograft model (B-ALL) in vivo }\end{array}$ & 153 \\
\hline scFvCD33:sTRAIL & CD33 & $\begin{array}{l}\text { Increased antitumor activity against hematologic tumor } \\
\text { cell lines and AML primary cells in vitro }\end{array}$ & 154 \\
\hline scFvCD70:TRAILmutRs & CD70 & $\begin{array}{l}\text { Increased bioactivity with cytotoxic targeting to hematologic } \\
\text { and solid tumor cell lines in vitro }\end{array}$ & 155 \\
\hline scFv:G28-TRAIL & CD40 & $\begin{array}{l}\text { Bifunctional molecule that not only activates TRAIL } \\
\text { pathway but also induces DC maturation leading to immune cells activation. } \\
\text { This was tested in Fibrosarcoma cell lines in vitro }\end{array}$ & 156 \\
\hline MSC.scFvCD20-sTRAIL & CD20 & $\begin{array}{l}\text { Increased antitumor activity with no side effects against: } \\
\text { A) Hematologic tumor cell lines and normal primary cells in vitro } \\
\text { B) Tumor xenograft model }{ }^{158} \text { in vivo }\end{array}$ & 157 \\
\hline
\end{tabular}


scTRAIL molecules comprising a covalent linkage of the C-terminal Val280 and the N-terminal position 122 by only 2 amino acid residues. These modified scTRAIL molecules showed increased thermal stability, which resulted in increased potent antitumor activity in vivo and in vitro. ${ }^{160}$

Another novel DR5scFv design, was introduced in early 2016 and could possibly be considered a candidate for cancer treatment. ${ }^{161}$

In the following part we are going to discuss different nanodesigns delivering TRAIL.

\section{Nanoparticles: Guided missiles and Trojan horses for TRAIL}

Developments in nanotechnology have opened new horizons for nanomedicine and regenerative medicine. Field of Nanomedicine has grown exponentially in the past few years and substantial fraction of information has been added into the existing pool of knowledge related to identification of strategies to nanotechnologically deliver therapeutic drugs. Figure 3 shows how nanoparticles deliver the payload to the target sites.

The physico-chemical properties of nanoparticles such as their 3-D configuration, shape, volume, flexibility, electrostatic proper- ties, may significantly modify their interactions at sub-molecular or atomic levels.

Using high-throughput technologies, it has been shown that interaction of Nanoparticles with proteins, cells, membranes, DNA and organelles triggers a series of nanoparticle/biological interfaces that is dependent on colloidal forces and bio-physicochemical interactions. These interactions lead to particle wrapping, formation of protein coronas, cellular uptake and biocatalytic mechanisms, which may have bio-adverse or bio-compatible outcomes.

Therefore, delivering TRAIL molecule using nanodesigns will improve the outcome of its cytotoxic effects.

Multifunctional and multilayered micro- or nanoscale structures by using of Layer-by-Layer assembly have shown potential as carriers of different drugs. Cross-linked albumin nanoparticles loaded with doxorubicin ${ }^{111}$ were fabricated with TRAIL and a polysaccharide, alginate (ALG), using layer-by-layer technique. Mechanistically it has been revealed that assembled core/shell structure of the NPs can be effectively internalized by cancer cells. TRAIL was located at outer layer of the TRAIL/ALG-BSA NPs, to selectively target DR overexpressing cancer cells. ${ }^{162}$

Artificially designed lipid nanoparticles (NPs) coated with TRAIL have been shown to considerably enhance apoptosis in in

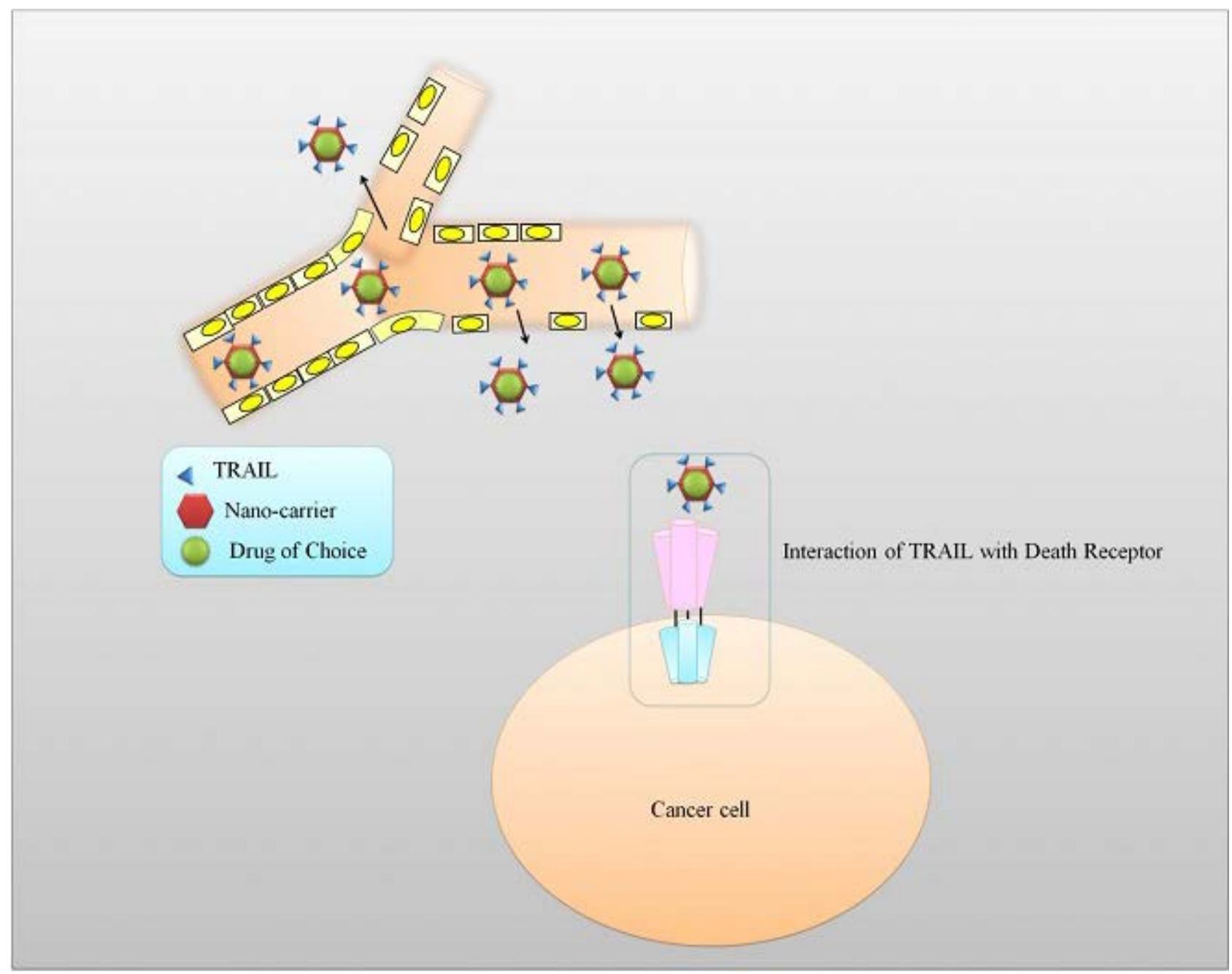

Figure 3. Nanoparticles loaded with TRAIL can target specific tumor sites. Nanoparticle design target tumors through passive targeting properties also known as enhanced permeation and retention. In active targeting, the particle is designed to target specific tumor receptors. 
leukemic cells. ${ }^{163}$ Targeted iron oxide NPs coated with chlorotoxin (CTX) and chitosan-polyethylene glycol-polyethyleneimine copolymer effectively delivered TRAIL. Tumor growth was substantially reduced in xenografted mice systemically administered with NP-TRAIL-CTX. ${ }^{164}$

Oxaliplatin immunohybrid NPs effectively delivered antiTRAIL and notably inhibited tumor growth in xenografted tumor models. ${ }^{165}$

Recently a novel cationic lipid (DOBP) was designed for eradication of tumor. ${ }^{166}$ This was designed similarly to $1,2-$ di-(9Zoctadecenoyl)-3-trimethylammonium-propane (DOTAP, a cationic lipid) by modifying trimethylammonium of DOTAP and converting it into biguanide and carrying TRAIL expressing plasmids. This biguanide group acted similarly to metformin and activated AMPK signaling pathway. ${ }^{166,167}$ The cytotoxicity of DOBP-LPDTRAIL NPs was tested in vitro in H460 cells and in nude mice xenografted with $\mathrm{H} 460$ cells and showed apoptotic superiority than DOTAP-LPD-TRAIL NPs. Therefore, DOBP serves as versatile cationic carrier facilitating TRAIL gene delivery, and enhancing TRAIL apoptotic effects through biguanide's anti cancerous effects and AMPK pathway activation.

\section{Pulmonary route for gene delivery}

Directly delivered anti-cancer agents via pulmonary route has also shown potential. In accordance with this approach, Inhalable NPs made of human serum albumin (HSA) conjugated with octyl aldehyde and doxorubicin and adsorbed with TRAIL (TRAIL/Dox HAS) revealed notable efficacy mainly because of hydrophobicity and self-assembly. TRAIL/Dox HSA-NPs had significant deposition in mouse lungs and Dox-HSA and TRAIL showed sustained release over 3 days. TRAIL/Dox HSA-NPs administered via pulmonary route considerably reduced tumor formation in $\mathrm{BALB} / \mathrm{c}$ nude mice bearing $\mathrm{H} 226$ cell-induced metastatic tumors. ${ }^{168}$

\section{Dendrimers}

Therapeutics conjugated to nanoparticle-forming biodegradable polymers have been engineered to maximize "sustained release" and avoid 'burst release' associated with NPs. To maximize the efficiency and drug delivery, dendrimers are being used which are synthetic, symmetrically structured and highly branched macromolecules. Modifications of terminal functionalities of the dendrimers (such as PPIs and PAMAMs) enable targeted delivery of the drugs of choice, while interior cavities can be utilized to load hydrophilic and hydrophobic drugs.

Triazine-modified dendrimer G5-DAT66 effectively delivered TRAIL remarkably inhibited tumor growth in osteosarcoma-bearing mice. ${ }^{169}$

TRAIL condensed with Transferrin ${ }^{170}$ - modified polyamidoamine dendrimer (PAMAM) has been shown to efficiently enhance median survival time of C6 glioma-bearing rat brain. ${ }^{171}$

\section{Future directions}

Benefiting from TRAIL molecular characteristics as a tumor cytotoxic agent will definitely lead to a revolution in cancer treatment. The quest for an ultimate TRAIL preparation is still going. Lessons learned from the past will definitely help paving the road for future ultimate usage of TRAIL molecule. Future directions should focus on:

- Identifications of certain biomarkers predicting responsiveness to TRAIL will help clinicians in selecting patients sensitive to this unique molecule.
Identification of generalized biomarkers, like GALNT14 the O-glycosylation enzyme as a predictor to TRAIL sensitivity ${ }^{172}$ did not significantly correlate with clinical response to dulanermin in clinical practice. Therefore, more customized biomarkers should be considered in the future.

- Introducing the kinome profiling strategy to gear up the personalized medicine approach and enhance the knowledge of different interactions in TRAIL pathway. ${ }^{173}$ Personalized medicine, a promising approach utilizing quantitative genomics, proteomics and kinomics, could help us better recognizing different targeted pathways that can enhance TRAIL therapeutics in mono or combinatorial approaches. ${ }^{174}$

- As the poor clinical outcome of TRAIL MoAB preparation was contributed to their low potency, creating more humanized anti DR-4/DR-5 will potentiate their tumoral cytotoxicity in vivo. Inducing mutations in $\mathrm{Fc}$ portion will increase affinity of MoAB to the targeted receptors, hence enhancing its killing ability. Recently, Wang et al. revealed humanized anti DR-4 and anti DR-5 coined as HuD114 and HuG4.2 respectively. ${ }^{175}$ These humanized antibodies have shown more killing ability than conventional TRAIL MoAB. Also introducing S267E/L328f double mutation in the Fc portion improved receptor-binding affinity more than S267E single mutation.

- To avoid the pitfalls of old TRAIL preparations in achieving good clinical outcomes, these new preparations need to be tested in genetically modified mouse models, which carry a tumor microenvironment similar to the human spectrum ${ }^{176,177}$ before proceeding to clinical field.

- The advancement in biomolecular technology and drug designs offer variable options of $\mathrm{scFv}$ and fusion protein actively targeting cancer cells with enhanced TRAIL apoptotic effects. These novel designs need to be advanced in clinical fields for optimized cancer TRAIL therapy.

- Incorporating nanotechnology will definitely improves the outcomes of different TRAIL therapeutics. The nano carriers drugs will help dealing with metastatic disease though selective cancer targeting and enhanced pharmacokinetics. ${ }^{170,178}$

- Systemically administered therapeutics using nano-carriers require strategies to overcome nonspecific uptake by non-targeted and mononuclear phagocytic cells. To maximize differential targeting, frequently overexpressed surface marker (receptors or antigens) should be considered. For an effective liposomal delivery to B-cell receptors using an anti-CD19 monoclonal antibody, density of receptors may range from 104 to 105 copies/cell. Those cells which have low density are not efficiently targeted. ${ }^{179,180}$ It has previously been reported that a density of ErbB2 receptors in a range of 105 copies/cell significantly improved therapeutic efficiency of an anti-ErbB2-targeted liposomally delivered doxorubicin $^{111}$ as compared to nontargeted counterpart.

- There are some exciting pieces of evidence suggesting that higher binding affinity may dramatically reduce nanocarrier penetration mainly because of a 'binding-site barrier', where the nanocarriers strongly bind to the targets and cannot penetrate into tissues. ${ }^{181}$

Therefore affinity and targeting can be increased by multivalent binding effects (or avidity). The collective binding in multivalently interacting molecules is considerably higher than monovalent binding.

\section{Conclusions and final remarks}

Inducing apoptosis in cancer cells, appeal as an effective cancer treatment strategy that can work generally in any type of can- 
cer despite the underlying genetic, molecular changes. TRAIL, a naturally occurring molecule, was proven to successfully achieve this target of apoptosis induction selectively in cancer cells. Despite its ability to overcome the frequently observed resistance against chemotherapeutics and radio-therapeutics, interacting with CSCs self-renewal pathways as well as many other apoptotic properties, maximum clinical benefits from this molecule have not yet been achieved. This could be attributed to resistance factors that are yet to be explored or extensively studied, or to the efficacy of clinically available TRAIL based therapeutics. It is also to be noted, that the relation between TRAIL and immunomodulatory cancer therapies is yet to be fully explored. Therefore, future approaches should focus on developing an optimum TRAIL preparation to maximize the benefits from such an extraordinary apoptotic molecule.

\section{References}

1. Hanahan D, Weinberg RA. Hallmarks of cancer: the next generation. Cell 2011;144:646-74.

2. Wiley SR, Schooley K, Smolak PJ, et al. Identification and characterization of a new member of the TNF family that induces apoptosis. Immunity 1995;3:673-82.

3. Ivanov VN, Bhoumik A, Ronai Z. Death receptors and melanoma resistance to apoptosis. Oncogene 2003;22:315261.

4. LeBlanc H, Lawrence D, Varfolomeev E, et al. Tumor-cell resistance to death receptor--induced apoptosis through mutational inactivation of the proapoptotic Bcl-2 homolog Bax. Nature Med 2002;8:274-81.

5. Ozoren N, El-Deiry WS. Cell surface death receptor signaling in normal and cancer cells. Semin Cancer Biol 2003;13:13547.

6. Wajant H, Pfizenmaier K, Scheurich P. Tumor necrosis factor signaling. Cell Death Differ 2003;10:45-65.

7. Faustman DL, Davis M. TNF Receptor 2 and disease: autoimmunity and regenerative medicine. Front Immunol 2013;4:478.

8. Gupta S. A decision between life and death during TNF-alphainduced signaling. J Clin Immunol 2002;22:185-94.

9. Pan G, Ni J, Wei YF, et al. An antagonist decoy receptor and a death domain-containing receptor for TRAIL. Science (New York, NY) 1997;277:815-8.

10. Pan G, O'Rourke K, Chinnaiyan AM, et al. The receptor for the cytotoxic ligand TRAIL. Science (New York, NY) 1997;276:111-3

11. Degli-Esposti MA, Dougall WC, Smolak PJ, et al. The novel receptor TRAIL-R4 induces NF-kappaB and protects against TRAIL-mediated apoptosis, yet retains an incomplete death domain. Immunity 1997; 7:813-20.

12. Walczak H, Degli-Esposti MA, Johnson RS, et al. TRAIL-R2: a novel apoptosis-mediating receptor for TRAIL. EMBO J 1997; 16:5386-97.

13. Marsters SA, Sheridan JP, Pitti RM, et al. A novel receptor for Apo2L/TRAIL contains a truncated death domain. Curr Biol 1997;7:1003-6.

14. Wu GS, Burns TF, McDonald ER, 3rd, et al. KILLER/DR5 is a DNA damage-inducible p53-regulated death receptor gene. Nature Genet 1997;17:141-3.

15. Sheridan JP, Marsters SA, Pitti RM, et al. Control of TRAILinduced apoptosis by a family of signaling and decoy receptors. Science (New York, NY) 1997;277:818-21.

16. Chaudhary PM, Eby M, Jasmin A, et al. Death receptor 5, a new member of the TNFR family, and DR4 induce FADDdependent apoptosis and activate the NF-kappaB pathway. Immunity 1997;7:821-30.

17. Zhang XD, Franco A, Myers K, et al. Relation of TNF-related apoptosis-inducing ligand (TRAIL) receptor and FLICEinhibitory protein expression to TRAIL-induced apoptosis of melanoma. Cancer Res 1999;59:2747-53.

18. Zhang XD, Nguyen T, Thomas WD, et al. Mechanisms of resistance of normal cells to TRAIL induced apoptosis vary between different cell types. FEBS Lett 2000;482:193-9.

19. Bavi P, Prabhakaran SE, Abubaker J, et al. Prognostic significance of TRAIL death receptors in Middle Eastern colorectal carcinomas and their correlation to oncogenic KRAS alterations. Mol Cancer 2010;9:203.

20. Cooper WA, Kohonen-Corish MR, Zhuang L, et al. Role and prognostic significance of tumor necrosis factor-related apoptosis-inducing ligand death receptor DR5 in nonsmall-cell lung cancer and precursor lesions. Cancer 2008;113:135-42.

21. Dong HP, Kleinberg L, Silins I, et al. Death receptor expression is associated with poor response to chemotherapy and shorter survival in metastatic ovarian carcinoma. Cancer 2008; 112:84-93.

22. Elrod HA, Fan S, Muller S, et al. Analysis of death receptor 5 and caspase- 8 expression in primary and metastatic head and neck squamous cell carcinoma and their prognostic impact. PLoS One 2010;5:e12178.

23. Ganten TM, Sykora J, Koschny R, et al. Prognostic significance of tumour necrosis factor-related apoptosis-inducing ligand (TRAIL) receptor expression in patients with breast cancer. J Mol Med (Berlin, Germany) 2009;87:995-1007.

24. Haselmann V, Kurz A, Bertsch U, et al. Nuclear death receptor TRAIL-R2 inhibits maturation of let-7 and promotes proliferation of pancreatic and other tumor cells. Gastroenterology 2014;146:278-90.

25. Kuijlen JM, Mooij JJ, Platteel I, et al. TRAIL-receptor expression is an independent prognostic factor for survival in patients with a primary glioblastoma multiforme. J NeuroOncol 2006;78:161-71.

26. Li Y, Jin X, Li J, et al. Expression of TRAIL, DR4, and DR5 in bladder cancer: correlation with response to adjuvant therapy and implications of prognosis. Urology 2012;79:968.e715.

27. Maduro JH, Noordhuis MG, ten Hoor KA, et al. The prognostic value of TRAIL and its death receptors in cervical cancer. Int J Radiat Oncol Biol Physics 2009;75:203-11.

28. Ashkenazi A. Targeting death and decoy receptors of the tumour-necrosis factor superfamily. Nature Rev Cancer 2002;2:420-30.

29. Mongkolsapaya J, Grimes JM, Chen N, et al. Structure of the TRAIL-DR5 complex reveals mechanisms conferring specificity in apoptotic initiation. Nature Struct Biol 1999;6:104853.

30. Hymowitz SG, Christinger HW, Fuh G, et al. Triggering cell death: the crystal structure of Apo2L/TRAIL in a complex with death receptor 5. Mol Cell 1999;4:563-71.

31. Bodmer JL, Meier P, Tschopp J, Schneider P. Cysteine 230 is essential for the structure and activity of the cytotoxic ligand TRAIL. J Biol Chem 2000;275:20632-7.

32. Jin Z, Li Y, Pitti R, et al. Cullin3-based polyubiquitination and p62-dependent aggregation of caspase- 8 mediate extrinsic apoptosis signaling. Cell 2009;137:721-35.

33. Green DR. Apoptotic pathways: paper wraps stone blunts scissors. Cell 2000;102:1-4.

34. Naoum GE, Tawadros F, Farooqi AA, et al. Role of nanotech- 
nology and gene delivery systems in TRAIL-based therapies. Ecancermedicalscience 2016;10:660.

35. Fulda S, Meyer E, Friesen C, et al. Cell type specific involvement of death receptor and mitochondrial pathways in druginduced apoptosis. Oncogene 2001;20:1063-75.

36. Scaffidi C, Fulda S, Srinivasan A, et al. Two CD95 (APO1/Fas) signaling pathways. EMBO J 1998;17:1675-87.

37. Peter ME, Krammer PH. Mechanisms of CD95 (APO-1/Fas)mediated apoptosis. Curr Opin Immunol 1998;10:545-51.

38. Jost PJ, Grabow S, Gray D, et al. XIAP discriminates between type I and type II FAS-induced apoptosis. Nature 2009;460:1035-9.

39. Deveraux QL, Takahashi R, Salvesen GS, Reed JC. X-linked IAP is a direct inhibitor of cell-death proteases. Nature 1997;388:300-4.

40. Galluzzi L, Vitale I, Abrams JM, et al. Molecular definitions of cell death subroutines: recommendations of the Nomenclature Committee on Cell Death 2012. Cell Death Differ 2012;19:107-20.

41. Wilson NS, Dixit V, Ashkenazi A. Death receptor signal transducers: nodes of coordination in immune signaling networks. Nature Immunol 2009;10:348-55.

42. Vandenabeele P, Galluzzi L, Vanden Berghe T, Kroemer G. Molecular mechanisms of necroptosis: an ordered cellular explosion. Nature Rev Mol Cell Biol 2010;11:700-14.

43. Holler N, Zaru R, Micheau O, et al. Fas triggers an alternative, caspase-8-independent cell death pathway using the kinase RIP as effector molecule. Nature Immunol 2000;1:489-95.

44. Cai Z, Jitkaew S, Zhao J, et al. Plasma membrane translocation of trimerized MLKL protein is required for TNF-induced necroptosis. Nature Cell Biol 2014;16:55-65.

45. Eggert A, Grotzer MA, Zuzak TJ, Wiewrodt BR, Ho R, Ikegaki N, et al. Resistance to tumor necrosis factor-related apoptosis-inducing ligand (TRAIL)-induced apoptosis in neuroblastoma cells correlates with a loss of caspase- 8 expression. Cancer Res 2001;61:1314-9.

46. Gonzalvez F, Lawrence D, Yang B, et al. TRAF2 Sets a threshold for extrinsic apoptosis by tagging caspase- 8 with a ubiquitin shutoff timer. Mol Cell 2012;48:888-99.

47. Abdollahi T, Robertson NM, Abdollahi A, Litwack G. Identification of interleukin 8 as an inhibitor of tumor necrosis factor-related apoptosis-inducing ligand-induced apoptosis in the ovarian carcinoma cell line OVCAR3. Cancer Res 2003;63:4521-6.

48. Wilson C, Wilson T, Johnston PG, et al. Interleukin-8 signaling attenuates TRAIL- and chemotherapy-induced apoptosis through transcriptional regulation of c-FLIP in prostate cancer cells. Mol Cancer Ther 2008;7:2649-61.

49. Deng $\mathrm{Y}$, Lin $\mathrm{Y}, \mathrm{Wu} \mathrm{X}$. TRAIL-induced apoptosis requires Bax-dependent mitochondrial release of Smac/DIABLO. Genes Dev 2002;16:33-45.

50. Wang S, El-Deiry WS. Requirement of p53 targets in chemosensitization of colonic carcinoma to death ligand therapy. Proc Natl Acad Sci U S A 2003;100:15095-100.

51. Arafat W, Zhou T, Naoum GE, Buchsbaum DJ. Targeted radiotherapy potentiates the cytotoxicity of a novel antihuman DR5 monoclonal antibody and the adenovirus encoding soluble TRAIL in prostate cancer. J Egypt Natl Cancer Instit 2015;27:205-15.

52. Ravi R, Bedi A. Requirement of BAX for TRAIL/Apo2Linduced apoptosis of colorectal cancers: synergism with sulindac-mediated inhibition of $\mathrm{Bcl}-\mathrm{x}(\mathrm{L})$. Cancer Res 2002;62:1583-7.

53. Wan Z, Pan H, Liu S, et al. Downregulation of SNAIL sensi- tizes hepatocellular carcinoma cells to TRAIL-induced apoptosis by regulating the NF-kappaB pathway. Oncol Rep 2015;33:1560-6.

54. Walczak H, Miller RE, Ariail K, et al. Tumoricidal activity of tumor necrosis factor-related apoptosis-inducing ligand in vivo. Nature Med 1999;5:157-63.

55. McCarthy MM, DiVito KA, Sznol M, et al. Expression of tumor necrosis factor--related apoptosis-inducing ligand receptors 1 and 2 in melanoma. Clin Cancer Res 2006;12:3856-63.

56. Olivier M, Hollstein M, Hainaut P. TP53 mutations in human cancers: origins, consequences, and clinical use. Cold Spring Harbor Perspect Biol 2010;2:a001008.

57. Niemoeller OM, Belka C. Radiotherapy and TRAIL for cancer therapy. Cancer Lett 2013;332:184-93.

58. Srivastava RK. TRAIL/Apo-2L: mechanisms and clinical applications in cancer. Neoplasia (New York, NY) 2001;3:535-46.

59. Wu XX, Ogawa O, Kakehi Y. TRAIL and chemotherapeutic drugs in cancer therapy. Vitamins Hormones 2004;67:365-83.

60. Wang H, Yang T, Wu X. 5-Fluorouracil preferentially sensitizes mutant KRAS non-small cell lung carcinoma cells to TRAIL-induced apoptosis. Mol Oncol 2015;9:1815-24.

61. Zhang X, Zhao J, Zhu W, et al. Synergistic Effect of subtoxic-dose cisplatin and TRAIL to mediate apoptosis by downregulating decoy receptor 2 and up-regulating caspase- 8 , caspase- 9 and Bax expression on NCI-H460 and A549 cells. Iranian J Basic Med Sci 2013;16:710-8.

62. Baritaki S, Huerta-Yepez S, Sakai T, et al. Chemotherapeutic drugs sensitize cancer cells to TRAIL-mediated apoptosis: upregulation of DR5 and inhibition of Yin Yang 1. Mol Cancer Ther 2007;6:1387-99.

63. Nagane M, Pan G, Weddle JJ, et al. Increased death receptor 5 expression by chemotherapeutic agents in human gliomas causes synergistic cytotoxicity with tumor necrosis factorrelated apoptosis-inducing ligand in vitro and in vivo. Cancer Res 2000;60:847-53.

64. Muhlethaler-Mottet A, Bourloud KB, Auderset K, et al. Drugmediated sensitization to TRAIL-induced apoptosis in caspase-8-complemented neuroblastoma cells proceeds via activation of intrinsic and extrinsic pathways and caspase-dependent cleavage of XIAP, Bcl-xL and RIP. Oncogene 2004;23:5415-25.

65. Cuello M, Ettenberg SA, Nau MM, Lipkowitz S. Synergistic induction of apoptosis by the combination of trail and chemotherapy in chemoresistant ovarian cancer cells. Gynecol Oncol 2001;81:380-90.

66. Johnson TR, Stone K, Nikrad M, et al. The proteasome inhibitor PS-341 overcomes TRAIL resistance in Bax and caspase 9-negative or Bcl-xL overexpressing cells. Oncogene 2003;22:4953-63.

67. Chinnaiyan AM, Prasad U, Shankar S, et al. Combined effect of tumor necrosis factor-related apoptosis-inducing ligand and ionizing radiation in breast cancer therapy. Proc Natl Acad Sci U S Am 2000;97:1754-9.

68. Shankar S, Singh TR, Srivastava RK. Ionizing radiation enhances the therapeutic potential of TRAIL in prostate cancer in vitro and in vivo: Intracellular mechanisms. Prostate 2004;61:35-49.

69. Signore M, Ricci-Vitiani L, De Maria R. Targeting apoptosis pathways in cancer stem cells. Cancer Lett 2013;332:374-82.

70. Sussman RT, Ricci MS, Hart LS, et al. Chemotherapy-resistant side-population of colon cancer cells has a higher sensitivity to TRAIL than the non-SP, a higher expression of c-Myc 
and TRAIL-receptor DR4. Cancer Biol Ther 2007;6:1490-5.

71. Yin $\mathrm{S}, \mathrm{Xu} \mathrm{L}$, Bandyopadhyay $\mathrm{S}$, et al. Cisplatin and TRAIL enhance breast cancer stem cell death. Int $\mathrm{J}$ Oncol 2011;39:891-8.

72. Kurita S, Mott JL, Almada LL, et al. GLI3-dependent repression of DR4 mediates hedgehog antagonism of TRAILinduced apoptosis. Oncogene 2010;29:4848-58.

73. Kurita S, Mott JL, Cazanave SC, et al. Hedgehog inhibition promotes a switch from Type II to Type I cell death receptor signaling in cancer cells. PLoS One 2011;6:e18330.

74. Portanova P, Notaro A, Pellerito O, et al. Notch inhibition restores TRAIL-mediated apoptosis via AP1-dependent upregulation of DR4 and DR5 TRAIL receptors in MDA-MB231 breast cancer cells. Int J Oncol 2013;43:121-30.

75. Roberts NJ, Zhou S, Diaz LA, Jr., Holdhoff M. Systemic use of tumor necrosis factor alpha as an anticancer agent. Oncotarget 2011;2:739-51.

76. Creaven PJ, Brenner DE, Cowens JW, et al. A phase I clinical trial of recombinant human tumor necrosis factor given daily for five days. Cancer Chemother Pharmacol 1989;23:186-91.

77. Ogasawara J, Watanabe-Fukunaga R, Adachi M, et al. Lethal effect of the anti-Fas antibody in mice. Nature 1993;364:8069.

78. Imao M, Nagaki M, Imose M, Moriwaki H. Differential caspase-9-dependent signaling pathway between tumor necrosis factor receptor- and Fas-mediated hepatocyte apoptosis in mice. Liver Int 2006;26:137-46.

79. Ashkenazi A, Pai RC, Fong S, et al. Safety and antitumor activity of recombinant soluble Apo2 ligand. J Clin Investig 1999;104:155-62.

80. Nesterov A, Nikrad M, Johnson T, Kraft AS. Oncogenic Ras sensitizes normal human cells to tumor necrosis factor-alpharelated apoptosis-inducing ligand-induced apoptosis. Cancer Res 2004;64:3922-7.

81. Pitti RM, Marsters SA, Ruppert S, et al. Induction of apoptosis by Apo-2 ligand, a new member of the tumor necrosis factor cytokine family. J Biol Chem 1996;271:12687-90.

82. Schneider P. Production of recombinant TRAIL and TRAIL receptor: $\mathrm{Fc}$ chimeric proteins. Methods Enzymol 2000;322:325-45.

83. Ganten TM, Koschny R, Sykora J, et al. Preclinical differentiation between apparently safe and potentially hepatotoxic applications of TRAIL either alone or in combination with chemotherapeutic drugs. Clin Cancer Res 2006;12:2640-6.

84. Lawrence D, Shahrokh Z, Marsters S, et al. Differential hepatocyte toxicity of recombinant Apo2L/TRAIL versions. Nature Med 2001;7:383-5.

85. Gores GJ, Kaufmann SH. Is TRAIL hepatotoxic? Hepatology (Baltimore, Md) 2001;34:3-6.

86. Koschny R, Walczak H, Ganten TM. The promise of TRAIL-potential and risks of a novel anticancer therapy. J Mol Med (Berlin, Germany) 2007;85:923-35.

87. Kelley RF, Totpal K, Lindstrom SH, et al. Receptor-selective mutants of apoptosis-inducing ligand 2/tumor necrosis factorrelated apoptosis-inducing ligand reveal a greater contribution of death receptor (DR) 5 than DR4 to apoptosis signaling. J Biol Chem 2005;280:2205-12.

88. Geng $\mathrm{CJH}$, Zhao Y, Ke X, et al. A multicenter, open-label phase II study of recombinant CPT (Circularly Permuted TRAIL) plus thalidomide in patients with relapsed and refractory multiple myeloma. Am J Hematol 2014;89:1037-42.

89. Fang F, Wang AP, Yang SF. Antitumor activity of a novel recombinant mutant human tumor necrosis factor-related apoptosis-inducing ligand. Acta Pharmacol Sinica
2005;26:1373-81.

90. Zhang XJ, Wen L, Wang FX, et al. [Combined effect of recombinant mutant human TRAIL and daunorubicin in inducing apoptosis of leukemia cell and its mechanism]. Zhongguo shi yan xue ye xue za zhi 2006;14:1123-8.

91. Wang YR, Wen SP, Wang FX, et al. [Apoptosis of the adriamycin-resistant leukemia cell line induced by the recombinant mutant human TNF-related apoptosis-inducing ligand combined with arsenic trioxide]. Zhongguo shi yan xue ye xue za zhi 2008;16:1055-9.

92. Griffith TS, Rauch CT, Smolak PJ, et al. Functional analysis of TRAIL receptors using monoclonal antibodies. J Immunology (Baltimore, Md: 1950) 1999;162:2597-605.

93. Takeda K, Yamaguchi N, Akiba H, et al. Induction of tumorspecific $\mathrm{T}$ cell immunity by anti-DR5 antibody therapy. J Exper Med 2004;199:437-48.

94. Yagita H, Takeda K, Hayakawa Y, et al. TRAIL and its receptors as targets for cancer therapy. Cancer Sci 2004;95:777-83.

95. Ichikawa K, Liu W, Zhao L, et al. Tumoricidal activity of a novel anti-human DR5 monoclonal antibody without hepatocyte cytotoxicity. Nature Med 2001;7:954-60.

96. Chuntharapai A, Dodge K, Grimmer K, et al. Isotype-dependent inhibition of tumor growth in vivo by monoclonal antibodies to death receptor 4. J Immunol (Baltimore, Md: 1950) 2001;166:4891-8.

97. Pukac L, Kanakaraj P, Humphreys R, et al. HGS-ETR1, a fully human TRAIL-receptor 1 monoclonal antibody, induces cell death in multiple tumour types in vitro and in vivo. $\mathrm{Br} \mathrm{J}$ Cancer 2005;92:1430-41.

98. Herbst RS, Eckhardt SG, Kurzrock R, et al. Phase I dose-escalation study of recombinant human Apo2L/TRAIL, a dual proapoptotic receptor agonist, in patients with advanced cancer. J Clin Oncol 2010;28:2839-46.

99. Soria JC, Smit E, Khayat D, et al. Phase $1 \mathrm{~b}$ study of dulanermin (recombinant human Apo2L/TRAIL) in combination with paclitaxel, carboplatin, and bevacizumab in patients with advanced non-squamous non-small-cell lung cancer. J Clin Oncol 2010;28:1527-33.

100. Soria JC, Mark Z, Zatloukal P, et al. Randomized phase II study of dulanermin in combination with paclitaxel, carboplatin, and bevacizumab in advanced non-small-cell lung cancer. J Clin Oncol 2011;29:4442-51.

101. Yee LHAB, Kozloff M, Wainberg Z, et al. Phase Ib study of recombinant human Apo2L/TRAIL plus irinotecan and cetuximab or FOLFIRI in metastatic colorectal cancer (mCRC) patients (pts): preliminary results. 54th Annual meeting of American society of Hematology; 2012.

102. Kasubhai SMBJ, Kozloff M, Kapp AV, et al. Phase Ib study of dulanermin combined with FOLFIRI (with or without bevacizumab [BV]) in previously treated patients (Pts) with metastatic colorectal cancer (mCRC). J Clin Oncol 2012 ASCO Annual Meeting Abstracts 2012;30:3543.

103. Sharma SdVE, Infante JR, Oldenhuis C, et al. Phase I trial of LBY135, a monoclonal antibody agonist to DR5, alone and in combination with capecitabine in advanced solid tumors. J Clin Oncol 2008 ASCO Annual Meeting Proceedings 2008;26:3538.

104. Yee LHAB, Kozloff M, Wainberg Z, et al. Phase Ib study of recombinant human Apo2L/TRAIL plus irinotecan and cetuximab or FOLFIRI in metastatic colorectal cancer (mCRC) patients (pts): preliminary results. ASCO Meeting Abstracts 2009 American Society of Clinical Oncology 2009;27:4129.

105. Kasubhai SM, Bendell JC, Kozloff M, et al. Phase Ib study of dulanermin combined with FOLFIRI (with or without beva- 
cizumab [BV]) in previously treated patients (Pts) with metastatic colorectal cancer (mCRC). J Clin Oncol 2012 ASCO Annual Meeting Abstracts 2012;30:3543.

106. Chen WQL, Hou J, Zhang X, et al. Phase Ib study of recombinant circularly permuted TRAIL (CPT) in relapsed or refractory multiple myeloma patients. 54th ASH Annual Meeting 2012:1857.

107. Chen W, Qiu L, Ke X, et al. Circularly permuted TRAIL (CPT) combined with thalidomide for the treatment of relapsed or refractory multiple myeloma: an open-label, multicenter phase II clinical trial. 54th Annual Meeting of American Society of Hematology, 2012.

108. Geng C, Hou J, Zhao Y, et al. A multicenter, open-label phase II study of recombinant CPT (Circularly Permuted TRAIL) plus thalidomide in patients with relapsed and refractory multiple myeloma. Am J Hematol 2014;89:1037-42.

109. Leong S, Cohen RB, Gustafson DL, et al. Mapatumumab, an antibody targeting TRAIL-R1, in Combination with paclitaxel and carboplatin in patients with advanced solid malignancies: results of a phase I and pharmacokinetic study. J Clin Oncol 2009;27:4413-21.

110. von Pawel J, Harvey JH, Spigel DR, et al. Phase II trial of mapatumumab, a fully human agonist monoclonal antibody to tumor necrosis factor-related apoptosis-inducing ligand receptor 1 (TRAIL-R1), in combination with paclitaxel and carboplatin in patients with advanced non-small-cell lung cancer. Clin Lung Cancer 2014;15:188-96.e2.

111. Sikic BIWH, von Mehren M, Lewis N, et al. A phase Ib study to assess the safety of lexatumumab, a human monoclonal antibody that activates TRAIL-R2, in combination with gemcitabine, pemetrexed, doxorubicin or FOLFIRI. J Clin Oncol 2007 ASCO Annual Meeting Proceedings 2007;25:14006.

112. Mom CH, Verweij J, Oldenhuis CN, et al. Mapatumumab, a fully human agonistic monoclonal antibody that targets TRAIL-R1, in combination with gemcitabine and cisplatin: a phase I study. Clin Cancer Res 2009;15:5584-90.

113. Tolcher AW, Mita M, Meropol NJ, et al. Phase I pharmacokinetic and biologic correlative study of mapatumumab, a fully human monoclonal antibody with agonist activity to tumor necrosis factor-related apoptosis-inducing ligand receptor-1. J Clin Oncol 2007;25:1390-5.

114. Hotte SJ, Hirte HW, Chen EX, et al. A phase 1 study of mapatumumab (fully human monoclonal antibody to TRAIL-R1) in patients with advanced solid malignancies. Clin Cancer Res 2008; 14:3450-5.

115. Younes A, Vose JM, Zelenetz AD, et al. A Phase $1 \mathrm{~b} / 2$ trial of mapatumumab in patients with relapsed/refractory nonHodgkin's lymphoma. Br J Cancer 2010;103:1783-7.

116. Greco FA, Bonomi P, Crawford J, et al. Phase 2 study of mapatumumab, a fully human agonistic monoclonal antibody which targets and activates the TRAIL receptor-1, in patients with advanced non-small cell lung cancer. Lung Cancer (Amsterdam, Netherlands) 2008;61:82-90.

117. Trarbach T, Moehler M, Heinemann V, et al. Phase II trial of mapatumumab, a fully human agonistic monoclonal antibody that targets and activates the tumour necrosis factor apoptosisinducing ligand receptor-1 (TRAIL-R1), in patients with refractory colorectal cancer. Br J Cancer 2010;102:506-12.

118. Forero-Torres A, Shah J, Wood T, et al. Phase I trial of weekly tigatuzumab, an agonistic humanized monoclonal antibody targeting death receptor 5 (DR5). Cancer Biother Radiopharm 2010;25:13-9.

119. Karapetis CSCP, Leighl NB, Durbin-Johnson B, et al. Phase II study of PRO95780 plus paclitaxel, carboplatin, and beva- cizumab (PCB) in non-small cell lung cancer (NSCLC). J Clin Oncol 2010 ASCO Annual Meeting Abstracts 2010;28:7535.

120. Reck M, Krzakowski M, Chmielowska E, et al. A randomized, double-blind, placebo-controlled phase 2 study of tigatuzum$\mathrm{ab}(\mathrm{CS}-1008)$ in combination with carboplatin/paclitaxel in patients with chemotherapy-naive metastatic/unresectable non-small cell lung cancer. Lung Cancer (Amsterdam, Netherlands) 2013;82:441-8.

121. Micheau O, Shirley S, Dufour F. Death receptors as targets in cancer. Br J Pharmacol 2013;169:1723-44.

122. Doi T, Murakami H, Ohtsu A, et al. Phase 1 study of conatumumab, a pro-apoptotic death receptor 5 agonist antibody, in Japanese patients with advanced solid tumors. Cancer Chemother Pharmacol 2011;68:733-41.

123. Herbst RS, Kurzrock R, Hong DS, et al. A first-in-human study of conatumumab in adult patients with advanced solid tumors. Clin Cancer Res 2010;16:5883-91.

124. Cohn AL, Tabernero J, Maurel J, et al. A randomized, placebo-controlled phase 2 study of ganitumab or conatumumab in combination with FOLFIRI for second-line treatment of mutant KRAS metastatic colorectal cancer. Ann Oncol 2013;24:1777-85.

125. Chawla SP, Tabernero J, Kindler HL, et al. Phase I evaluation of the safety of conatumumab (AMG 655) in combination with AMG 479 in patients (pts) with advanced, refractory solid tumors. J Clin Oncol 2010;28:3102.

126. Kindler HL, Richards DA, Garbo LE, et al. A randomized, placebo-controlled phase 2 study of ganitumab (AMG 479) or conatumumab (AMG 655) in combination with gemcitabine in patients with metastatic pancreatic cancer. Ann Oncol 2012;23:2834-42.

127. Paz-Ares L, Balint B, de Boer RH, et al. A randomized phase 2 study of paclitaxel and carboplatin with or without conatumumab for first-line treatment of advanced non-small-cell lung cancer. J Thorac Oncol 2013;8:329-37.

128. Peeters M, Price TJ, Cervantes A, et al. Randomized phase III study of panitumumab with fluorouracil, leucovorin, and irinotecan (FOLFIRI) compared with FOLFIRI alone as second-line treatment in patients with metastatic colorectal cancer. J Clin Oncol 2010;28:4706-13.

129. Camidge DR, Herbst RS, Gordon MS, et al. A phase I safety and pharmacokinetic study of the death receptor 5 agonistic antibody PRO95780 in patients with advanced malignancies. Clin Cancer Res 2010;16:1256-63.

130. Karapetis CS, Clingan PR, Leighl NB, et al. Phase II study of PRO95780 plus paclitaxel, carboplatin, and bevacizumab (PCB) in non-small cell lung cancer (NSCLC). J Clin Oncol 2010 ASCO Annual Meeting Abstracts 2010;28:7535.

131. Wittebol S, Ferrant A, Wickham NW, et al. Phase II study of PRO95780 plus rituximab in patients with relapsed follicular non-Hodgkin's lymphoma (NHL). J Clin Oncol 2010 ASCO Annual Meeting Abstracts 2010;28:e18511.

132. Baron AD, O'Bryant CL, Choi Y, et al. Phase Ib study of drozitumab combined with cetuximab (CET) plus irinotecan (IRI) or with FOLFIRI $\{+/-\}$ bevacizumab (BV) in previously treated patients (Pts) with metastatic colorectal cancer (mCRC). J Clin Oncol 2011 ASCO Annual Meeting Abstracts 2011;29:3581.

133. Rocha Lima CM, Bayraktar S, Flores AM, et al. Phase Ib study of drozitumab combined with first-line mFOLFOX6 plus bevacizumab in patients with metastatic colorectal cancer. Cancer Invest 2012;30:727-31.

134. Sharma S, de Vries EG, Infante JR, et al. Phase I trial of LBY135, a monoclonal antibody agonist to DR5, alone and in 
combination with capecitabine in advanced solid tumors. J Clin Oncol 2008 ASCO Annual Meeting Proceedings 2008;26:3538.

135. Plummer R, Attard G, Pacey S, et al. Phase 1 and pharmacokinetic study of lexatumumab in patients with advanced cancers. Clin Cancer Res 2007;13:6187-94.

136. Wakelee HA, Patnaik A, Sikic BI, et al. Phase I and pharmacokinetic study of lexatumumab (HGS-ETR2) given every 2 weeks in patients with advanced solid tumors. Ann Oncol 2010;21:376-81.

137. Merchant MS, Geller JI, Baird K, et al. Phase I trial and pharmacokinetic study of lexatumumab in pediatric patients with solid tumors. J Clin Oncol 2012;30:4141-7.

138. Sikic B, Wakelee H, Mehren MV, et al. A Phase $1 \mathrm{~b}$ study to assess the safety of lexatumumab, a human monoclonal antibody that activates TRAIL-R2, in combination with gemcitabine, pemetrexed, doxorubicin or FOLFIRI. J Clin Oncol 2007;25:14006.

139. Lemke J, von Karstedt S, Zinngrebe J, Walczak H. Getting TRAIL back on track for cancer therapy. Cell Death Differ 2014;21:1350-64.

140. Wang H, Davis JS, Wu X. Immunoglobulin Fe domain fusion to TRAIL significantly prolongs its plasma half-life and enhances its antitumor activity. Mol Cancer Ther 2014; 13:643-50.

141. Kobayashi E, Kishi H, Ozawa T, et al. A chimeric antigen receptor for TRAIL-receptor 1 induces apoptosis in various types of tumor cells. Biochem Biophys Res Commun 2014;453:798-803.

142. Su Y, Tatzel K, Wang X, et al. Mesothelin's minimal MUC16 binding moiety converts TR3 into a potent cancer therapeutic via hierarchical binding events at the plasma membrane. Oncotarget 2016;7:31534-49.

143. Tatzel K, Kuroki L, Dmitriev I, et al. Membrane-proximal TRAIL species are incapable of inducing short circuit apoptosis signaling: implications for drug development and basic cytokine biology. Sci Rep 2016 [Epub ahead of print].

144. Hendriks D, He Y, Koopmans I, et al. Programmed Death Ligand 1 (PD-L1)-targeted TRAIL combines PD-L1-mediated checkpoint inhibition with TRAIL-mediated apoptosis induction. Oncoimmunology 2016;5:e1202390.

145. Song X, Hong SH, Kwon WT, et al. Secretory TRAIL-Armed Natural Killer Cell-Based Therapy: In vitro and In vivo Colorectal Peritoneal Carcinomatosis Xenograft. Mol Cancer Ther 2016;15:1591-601.

146. Li R, Yang H, Jia D, et al. Fusion to an albumin-binding domain with a high affinity for albumin extends the circulatory half-life and enhances the in vivo antitumor effects of human TRAIL. J Control Release 2016;228:96-106.

147. Rivoltini L, Chiodoni C, Squarcina P, et al. TNF-Related Apoptosis-Inducing Ligand (TRAIL)-Armed Exosomes Deliver Proapoptotic Signals to Tumor Site. Clin Cancer Res. 2016;22:3499-512.

148. de Bruyn M, Bremer E, Helfrich W. Antibody-based fusion proteins to target death receptors in cancer. Cancer Lett 2013;332:175-83.

149. Arafat WO, Gomez-Navarro J, Buchsbaum DJ, et al. Effective single chain antibody ( $\mathrm{scFv}$ ) concentrations in vivo via adenoviral vector mediated expression of secretory scFv. Gene Ther 2002;9:256-62.

150. Arafat W, Gomez-Navarro J, Xiang J, et al. Antineoplastic effect of anti-erbB-2 intrabody is not correlated with scFv affinity for its target. Cancer Gene Ther 2000;7:1250-6.

151. Bremer E, de Bruyn M, Samplonius DF, et al. Targeted deliv- ery of a designed sTRAIL mutant results in superior apoptotic activity towards EGFR-positive tumor cells. J Mol Med (Berl) 2008;86:909-24.

152. Bremer E, van Dam GM, de Bruyn M, et al. Potent systemic anticancer activity of adenovirally expressed EGFR-selective TRAIL fusion protein. Mol Ther 2008;16:1919-26.

153. Stieglmaier J, Bremer E, Kellner C, et al. Selective induction of apoptosis in leukemic B-lymphoid cells by a CD19-specific TRAIL fusion protein. Cancer Immunol Immunother 2008;57:233-46.

154. ten Cate B, Bremer E, de Bruyn M, et al. A novel AML-selective TRAIL fusion protein that is superior to Gemtuzumab Ozogamicin in terms of in vitro selectivity, activity and stability. Leukemia 2009;23:1389-97.

155. Trebing J, El-Mesery M, Schafer V, et al. CD70-restricted specific activation of TRAILR1 or TRAILR2 using scFv-targeted TRAIL mutants. Cell Death Dis 2014;5:e1035.

156. El-Mesery M, Trebing J, Schafer V, et al. CD40-directed scFv-TRAIL fusion proteins induce CD40-restricted tumor cell death and activate dendritic cells. Cell Death Dis 2013;4:e916.

157. Yan C, Li S, Li Z, et al. Human umbilical cord mesenchymal stem cells as vehicles of CD20-specific TRAIL fusion protein delivery: a double-target therapy against non-Hodgkin's lymphoma. Mol Pharm 2013;10:142-51.

158. Wittebol SFA, Wickham NW, Fehrenbacher L, et al. Phase II study of PRO95780 plus rituximab in patients with relapsed follicular non-Hodgkin's lymphoma (NHL). J Clin Oncol 2010 ASCO Annual Meeting Abstracts 2010;28:e18511.

159. Park KJ, Lee SH, Kim TI, et al. A human scFv antibody against TRAIL receptor 2 induces autophagic cell death in both TRAIL-sensitive and TRAIL-resistant cancer cells. Cancer Res 2007;67:7327-34.

160. Siegemund M, Seifert O, Zarani M, et al. An optimized antibody-single-chain TRAIL fusion protein for cancer therapy. MAbs 2016;8:879-91.

161. Cheng X, Meng Q, Gao C, et al. Analysis of aDR5scFv with Specific Identification and Function. Monoclon Antib Immunodiagn Immunother 2016;35:25-31.

162. Cui W, Wang A, Zhao J, et al. Layer by layer assembly of albumin nanoparticles with selective recognition of tumor necrosis factor-related apoptosis-inducing ligand (TRAIL). J Colloid Interface Sci 2016;465:11-7.

163. De Miguel D, Gallego-Lleyda A, et al. Immunotherapy with liposome-bound TRAIL overcomes partial protection to soluble TRAIL-induced apoptosis offered by down-regulation of Bim in leukemic cells. Clin Translat Oncol 2015;17:657-67.

164. Wang K, Kievit FM, Jeon M, et al. Nanoparticle-mediated target delivery of TRAIL as gene therapy for glioblastoma. Adv Healthc Mater 2015;4:2719-26.

165. Tummala S, Gowthamarajan K, Satish Kumar MN, Wadhwani A. Oxaliplatin immuno hybrid nanoparticles for active targeting: an approach for enhanced apoptotic activity and drug delivery to colorectal tumors. Drug Deliv 2016;23:1773-87.

166. Luo C, Miao L, Zhao Y, et al. A novel cationic lipid with intrinsic antitumor activity to facilitate gene therapy of TRAIL DNA. Biomaterials 2016;102:239-48.

167. Morales DR, Morris AD. Metformin in cancer treatment and prevention. Annu Rev Med 2015;66:17-29.

168. Choi SH, Byeon HJ, Choi JS, et al. Inhalable self-assembled albumin nanoparticles for treating drug-resistant lung cancer. J Control Rel 2015;197:199-207.

169. Wang Y, Li L, Shao N, et al. Triazine-modified dendrimer for 
efficient TRAIL gene therapy in osteosarcoma. Acta Biomater 2015;17:115-24.

170. Sutradhar KB, Amin ML. Nanotechnology in cancer drug delivery and selective targeting. ISRN Nanotechnol 2014;2014:12.

171. Gao S, Li J, Jiang C, et al. Plasmid pORF-hTRAIL targeting to glioma using transferrin-modified polyamidoamine dendrimer. Drug Des Devel Ther 2016;10:1-11.

172. Wagner KW, Punnoose EA, Januario T, et al. Death-receptor O-glycosylation controls tumor-cell sensitivity to the proapoptotic ligand Apo2L/TRAIL. Nat Med 2007;13:10707.

173. Passante E, Wurstle ML, Hellwig CT, et al. Systems analysis of apoptosis protein expression allows the case-specific prediction of cell death responsiveness of melanoma cells. Cell Death Differ 2013;20:1521-31.

174. Arafat WO, Anderson J, Welaya K, et al. Triple therapy using radiation therapy (RT), Temozolomide (TMZ), and TRAIL agonist (TRA-8) enhances cell killing in primary glioma cancer stem cells associated with changes in distinct tyrosine kinase signaling cascades identified through kinomic analysis.
Int J Radiat Oncol 2013;87:S140.

175. Wang L, Park H. New highly potent antibodies to death receptors having Fc mutations to increase antitumor activity. Am Assoc Cancer Res AACR 2016 Annual Meeting 2016.

176. DuPage M, Jacks T. Genetically engineered mouse models of cancer reveal new insights about the antitumor immune response. Curr Opin Immunol 2013;25:192-9.

177. Frese KK, Tuveson DA. Maximizing mouse cancer models. Nat Rev Cancer 2007;7:645-58.

178. Ferrari M. Cancer nanotechnology: opportunities and challenges. Nat Rev Cancer 2005;5:161-71.

179. Lopes de Menezes DE, Pilarski LM, Allen TM. In vitro and in vivo targeting of immunoliposomal doxorubicin to human Bcell lymphoma. Cancer Res 1998;58:3320-30.

180. Park JW, Hong K, Kirpotin DB, et al. Anti-HER2 immunoliposomes: enhanced efficacy attributable to targeted delivery. Clin Cancer Res 2002;8:1172-81.

181. Adams GP, Schier R, McCall AM, et al. High affinity restricts the localization and tumor penetration of single-chain $\mathrm{fv}$ antibody molecules. Cancer Res 2001;61:4750-5. 